\title{
Australian Squatters, Convicts, and Capitalists: Dividing Up a Fast-Growing Frontier Pie 1821-1871
}
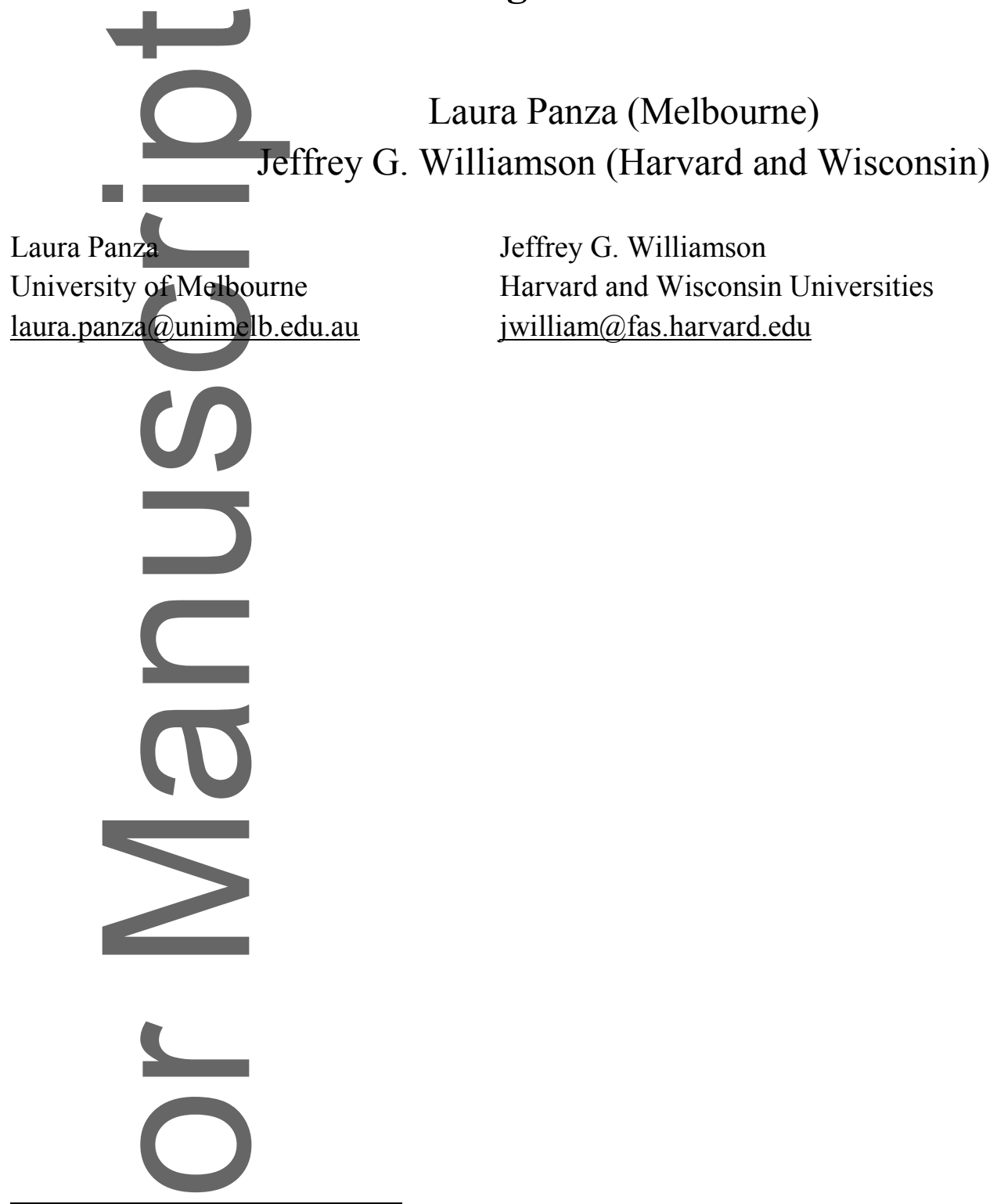

${ }^{1}$ We acknowledge with thanks the encouragement and comments of William Coleman, Hamish Maxwell-
Stewart, Tan McLean, David Merrett, Deborah Oxley, Martin Shanahan, Alan Taylor and especially Jeff Borland.
We are grateful to Taehyun Ryu for excellent research assistance. In addition, we acknowledge the useful
comments from three anonymous referees and from participants in seminars and conferences at ANU, APEBH
2017 (Melbournel, Adelaide, Essex, Monash, Melbourne and the Strasbourg 2017 World Cliometrics
Conference.

This is the author manuscript accepted for publication and has undergone full peer review but has not been through the copyediting, typesetting, pagination and proofreading process, which may lead to differences between this version and the Version of Record. Please cite this article as doi: 10.1111/ehr.12739.

This article is protected by copyright. All rights reserved. 


\section{Australian Squatters, Convicts, and Capitalists: Dividing Up a Fast-Growing Frontier Pie 1821-}

$1871^{\circ}$

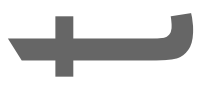

'[T]he historical information on long-run trends in economic inequality for Australia is reasonably abundant only for the past few decades, and becomes increasingly patchy before then, with quantitative information for the nineteenth century especially fragmentary.'

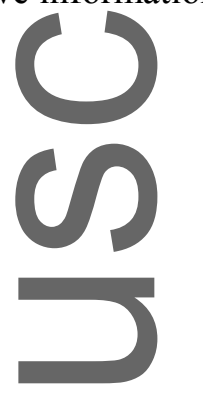

McLean, Why Australia prospered, p. 21.

Australian economic historians identify a long boom in the country's development from the 1820 s to 1890s, viewing it as their 'golden age' of economic progress. They are far less certain about distribution trends. Some argue that the fruits of prosperity were shared more or less equally, ${ }^{2}$ a view supported by many contemporaries, ${ }^{3}$ but such conventional wisdom has been challenged vigorously by others who maintain that working class living standards did not improve during the late nineteenth century ${ }^{4}$-The worsening in living standards has been attributed to employment instability and insecurity, associated with the prevalence of casual and seasonal unskilled labour. ${ }^{5}$ These contrasting views of Australian living standard trends are part of a broader debate centred on trends in income inequality during the nineteenth century, a debate which is based mainly on suggestive evidence and only weakly grounded empirically. While there is a well established historical literature covering Australia's first century of economic development, the inequality dynamics engendered by that

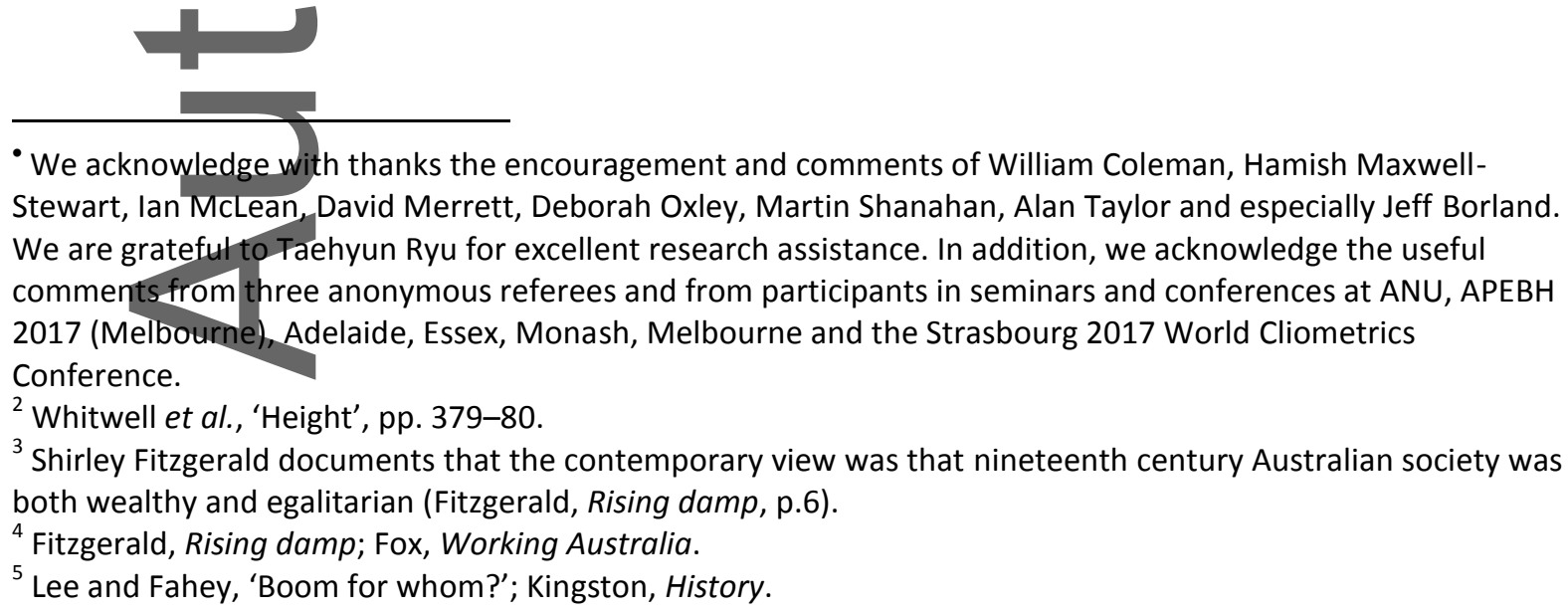

${ }^{3}$ Shirley Fitzgerald documents that the contemporary view was that nineteenth century Australian society was both wealthy and egalitarian (Fitzgerald, Rising damp, p.6).

${ }^{4}$ Fitzgerald, Rising damp; Fox, Working Australia.

${ }^{5}$ Lee and Fahey, 'Boom for whom?'; Kingston, History.

This article is protected by copyright. All rights reserved. 
growth performance has received very little empirical attention. ${ }^{6}$ The standard view of income distribution dynamics in commodity-exporting and land-abundant regions during the late nineteenth century globalisation wave argues that the industrial boom in Western Europe, together with the decline in worldwide transport costs, drove up the European demand for land-intensive commodities such as food and manufacturing intermediates. The resulting increase in their relative price raised the demand for land relative to labour, and thus the ratio of land rents to wages (the Stolper-Samuelson thesis), shifting the income distribution from labour to land, leading to an increase in inequality. ${ }^{7}$ Thus, land rent-to-wage ratio trends have become a frequently used proxy to gauge inequality change in land-abundant commodity exporters. ${ }^{8}$

Research documenting who gained the most from Australia's nineteenth century growth is very scarce? However, Martin Shanahan and John Wilson used the rent-to-wage ratio as their inequality proxy for the Australian colonies 1865-1913. ${ }^{10}$ Their findings challenge the standard frontier-inequality narrative for land-abundant countries, as they point to a decrease in the rent/wage ratio in one of the colonies, South Australia, and to a limited rise of the rent/wage ratio in New South Wales and Victoria later in the long nineteenth century, both of which run counter to the StolperSamuelson prediction. ${ }^{11}$ This suggests that Australia's experience may have been an exception to the late nineteenth century rule. But was it also likely to have been the case before the late nineteenth century globalization boom, that is from the 1820 s to the 1870 s? We think there are reasons to believe so: First, and in contrast to most commodity exporters, ${ }^{12}$ the Australian terms of trade did not boom during the half century up to the 1870s (Table 3 below), and the reasons seem clear. By the 1870 s, Australia supplied an enormous share of world wool exports and British wool imports (see section II below), so its own supply muted the influence of world demand on price. In addition, the decline in

\footnotetext{
${ }^{6}$ To our knowledge, only two scholars have offered any evidence speaking to distribution dynamics up to the 1870s, Thomas, 'Evolution of inequality' and Leigh, Battlers and billionaires.

${ }^{7}$ O'Rourke, Taylor, and Williamson, 'Factor price convergence'; Williamson, 'Land, labor and globalization'; idem, Trade and poverty.

${ }^{8}$ See also O'Rourke and Williamson, Globalization and history; Findlay and O'Rourke, Power and plenty.

${ }^{9}$ McLean, Why Australia prospered, p. 21.

${ }^{10}$ The Australian evidence on this point has been augmented more recently by earnings inequality measures (Greasley, Madsen, and Oxley, 'Real wages'; Anderson, 'Globalisation').

${ }^{11}$ Shanahan and Wilson, 'Measuring Inequality', Figure 2, p. 13.

${ }^{12}$ Williamson, Trade and poverty.
}

This article is protected by copyright. All rights reserved. 
transport costs - raising export prices at home - did not have its big impact until after the 1860s. Second, without a strong price tailwind, rapid increases in the land-labour ratio lowered the rent-wage ratio (as we shall see below in section II), rather than raising it as was so commonly the case for late nineteenth commodity exporters. Third, the half century up to the 1870 s involved a spectacular transition from a labour force dominated by coerced convict workers to one of free labour, a transition that implied a major redistribution from (subsidized) farmers, pastoralists and capitalists to labour, and a movement of ex-convicts up the wage ladder. Fourth, the large inflow of skilled migrants during the gold rush of the 1850 s outran the demand for skilled labour, suppressing any rise in the skill premium, thus preserving an egalitarian wage structure.

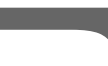

It should also be pointed out that up to the 1870 s Australia was an exceptionally fast grower. Australian GDP per worker grew at 2.4 per cent per annum between the 1820 s and the $1870 \mathrm{~s}$, almost twice that of the American juggernaut, and about three times that of the alleged imperial leader, Britain. ${ }^{13}$ In the United States, the fast growth years between independence and 1860 were coupled with a steep rise in Inequality, steep enough to force the United States into joining the Old World very unequal club. ${ }^{14}$ Did Australia undergo the same steep rise in inequality over the half-century before 1871? Probably not, since while the United States was undergoing impressive industrial growth, Australia was specializing in the export of minerals (small scale extraction) and wool. Both countries used cheap coerced labour, slaves in the American South and convicts in Australia, but their share of the labour force was much higher in Australia (more than half) than in America (about a fifth) early in the nineteenth century. More importantly, another key difference between the two countries was the timing of the emancipation of forced labour and the duration of their coerced employment. In Australia, the convicts were gradually 'emancipated' following the 1820 s in the sense that existing convicts eventually got their freedom, that the new convict inflow fell sharply after the 1830 s (except for Tasmania), and that Britain had practically ceased its convict transportation policy by the $1850 \mathrm{~s}$. In

\footnotetext{
${ }^{13}$ L. Panza and J. G. Williamson, 'Australian exceptionalism? Inequality and living standards 1821-1871', CEPR Discussion Paper 11756 (2017), p. 11. These estimates of fast growth in Australia's early economic history do not take into account the Aboriginal population. Recent research shows that if one considers all the residents of the country, Australia's GDP per capita declined until around 1830, so that the path of growth started thereafter (Hunter, 'Aboriginal legacy', p. 94).

${ }^{14}$ Lindert and Williamson, Unequal gains.
}

This article is protected by copyright. All rights reserved. 
contrast, the slaves in the American South were used as coerced labour for much longer, and emancipated only at the very end of the period, in $1865 .{ }^{15}$ Moreover, in Australia the transformation from conviet to free labour accelerated at a fast pace during the gold rush of the 1850s, when free immigration boomed. As the immigrant's skill content was higher than that of the locals, it helped skill growth to outrun skill demands, especially compared with North America. Thus, Australian immigration did not depress real wages of the unskilled. ${ }^{16}$

This paper offers new evidence supporting unambiguously the view that, in sharp contrast with the conventional frontier-cum-globalisation income distribution dynamics, Australian households of European origin-underwent a revolutionary levelling of incomes between the 1820s and the 1870s. 17 The Australian experience is also in sharp contrast with that of rapidly industrializing United States from 1800 to 1860 . These contrasting trajectories seem to have left their mark on the distributional character of the two economies into the twentieth century and even today. ${ }^{18}$ Specifically, this paper contributes to the literature by providing a comprehensive picture of income inequality trends in young Australia over the half-century before the 1870s. The evidence used here is based on an array of primary and secondary sources, enabling us to trace the development of various key indicators, such as land acreage, labour force by skill, land prices and rents, interest rates, wages and incomes by occupation, and commodity prices. As with all historical data, measurement error requires some qualification of conclusions. This is especially true of the pre-1850 years, ${ }^{19}$ but even for those early years we think our wage and income data are reliable. While there is no alternative dataset available, as far as we know, measurement errors are unlikely to overturn our findings.

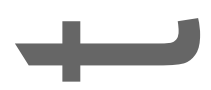

\footnotetext{
${ }^{15}$ Slavery was legalin all Thirteen Colonies at the time of the Declaration of Independence in 1776.

${ }^{16}$ Pope and Withers, 'Wage effects', p. 240. By testing empirically the real wage-migration linkage between 1861 and 1913 Pope and Withers (ibid.) find that Australian wages did not converge to British ones, unlike North American wages.

${ }^{17}$ We stress ' of European origins' here since, like the United States and other New World economies, information on indigenous peoples is too scarce to include them in any growth and distribution assessment over time (Hunter and Carmody, 'Aboriginal population').

${ }^{18}$ In 1980 , the top $1 \%$ had $4.8 \%$ of Australian income, while the figure was $8.2 \%$ in the US. In 2010 , the Australian figure was $9.2 \%$, and the US figure $17.5 \%$. While the two countries, and the rest of the OECD, underwent the same laws of motion, Australia remained the more egalitarian.

${ }^{19}$ See for example N. G. Butlin, J. Ginswick and P. Statham, 'Colonial statistics before 1850', Source Papers in Economic History (Australian National University, Canberra, 1986), p. i; Vamplew, Australians, pp. 452-3.
}

This article is protected by copyright. All rights reserved. 
Data availability constrains us also in two further dimensions: First, we are unable to include indigenous Australians in our analysis, as there are no consistent records documenting their market employment and wage experience. ${ }^{20}$ Making assumptions about the size of the indigenous labour force based on existing estimates of their population by Noel Butlin or Derek John Mulvaney and Johan Kamminga would be highly speculative. ${ }^{21}$ Moreover, Aboriginal people who participated in the settlers' labour market were usually remunerated in rations, rum and tobacco, not wages, and prices of these items are very hard to find for the outback (where most Aboriginals worked) ${ }^{22}$ Second, our estimates of female employment are not precise, as they were not accurately counted in the censusmeasured workforce, especially on sheep runs and in the goldfields, thus making many of them 'invisible'. ${ }^{23}$ Since the official censuses are the single source of data documenting the labour force in nineteenth century Australia, we have no other way to better include women in our analysis. ${ }^{24}$

Section II explores trends in income gaps between land and labour by estimating annually the wage-rental ratio. Here we provide evidence on the rate of land settlement, the behaviour of land values and land rents, and we document trends in land-labour ratios. Like the traditional globalisingfrontier literature, we begin by estimating trends in relative factor scarcities by computing relative factor prices, measured by wage-land value (per acre) and wage-land rent (per acre) ratios. We then expand this evidence by adding information on relative factor quantities thus to speak to relative income shares. The section also explores the forces driving land rents and thus the income share

\footnotetext{
${ }^{20}$ McLean (Why Australia prospered, p.43) argues that the main Aboriginal contribution to the country's growth was through the provision of labour; however, the evidence used is qualitative and fragmentary. ${ }^{21}$ Butlin, Our original aggression; Mulvaney and Kamminga, Prehistory. As the Aboriginal people were in open conflict with colonists over this period, they were often excluded from the white labour market. The establishment of Aboriginal protection boards from the mid-1850s imposed a set of institutional constraints on their participation in the Australian economy (Hunter, 'Aboriginal legacy', pp. 94-5).

${ }^{22}$ Hunter, 'Aboriginat legacy'.

${ }^{23}$ The categories of women not counted in nineteenth century colonial censuses were the following: married women, unless their occupation was indicated by their spouse; women accompanying husbands, fathers or brothers to the goldfields, who were for example cooking, washing, 'fossicking' and tending tents; women employed in occupations regarded as not respectable, such as prostitutes (Alford, 'Colonial women's employment').

${ }^{24}$ Under-counting women in the labour force implies a partial exaggeration of our estimated inequality decline, because the female labour force share increased during the nineteenth century and they had lower incomes than males.
}

This article is protected by copyright. All rights reserved. 
accruing to landowners and squatters. ${ }^{25}$ Here we assess the role of relative wool prices (and thus global commodity markets), interest rates (and thus global financial markets), and the exploitation rate of convicts-(reported in detail in Section III), de facto constituting a cheap labour subsidy of landed interests in the countryside and capitalists in the towns. The section establishes the earning gap between coerced convict and free labour, thus augmenting the rents and profits accruing to their landed and capitalist masters, respectively. It also documents the decline in the aggregate impact of that effect as the convict share of the labour force declined over time and eventually disappeared. Section IV offers some evidence regarding trends in earnings inequality among free workers by documenting the premiums earned by skilled mechanics and white collar employees, as well as a measure of the gap between average incomes in the middle and free labour at the bottom. With this background in hand, Section V reports our estimated functional income shares across the half-century for agricultural land rents, free unskilled labour (including the unskilled labour content of skilled labour), coerced convict labour, free skilled labour (or the premium received for skilled work), the imperial British income transfer, and that of residual claimants (capitalist income). Given where these categories fit in the income ranks - rental and capitalist incomes in the top quarter, skilled labour incomes in the second quarter, free unskilled labour in the third quarter, and coerced convict labour in the bottom quarter - this exercise traces out the evolution of overall inequality, and of its magnitude. Our findings point unambiguously to a steep decline in income inequality across the half-century between the 1820s and the 1870s. Section VI concludes.

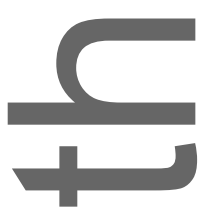

Table 1 reports pastoral and cultivated acreage from 1828 (when the data become available) to 1860 for New South Wales (which includes what would become Victoria in 1851 and Queensland in 1859), and 1861- 1 for all Australia except the colonies of Western Australia and Queensland, the data for

\footnotetext{
${ }^{25}$ Land was owned by the Crown, and it was sold at public auction when the colonial government needed the revenue. For the first three or four decades after 1815 , squatters simply settled the land without purchase.
}

This article is protected by copyright. All rights reserved. 
which are too limited. ${ }^{26}$ To be clear, we derive our acreage data from primary and secondary sources, which provide information on the land surveyed by the British Crown within settlement boundaries. Therefore, pastoral leases (pastoral land owned by the Crown) and so called 'waste lands' (land considered terra nullius inhabited) are also accounted for as long as they were within the settlement boundaries of surveyed land. ${ }^{27}$ While squatted land is also included if surveyed, its measurement is much less precise, especially on the frontier, as settlers ignored legal channels and fees. ${ }^{28}$ For these reasons, the acreage data we use represent a lower bound estimate of Australia's actual land endowment. Since this is more likely to have been true of early years, the acreage growth rate might be a bit exaggerated.

As is well known, the rate of settlement, driven mainly by pastoral expansion and sheep flocks, was spectacular. ${ }^{29}$ Acreage growth rates per annum were 6.5 per cent in $1828-39$, an impressive 17.5 per cent across the 1840s and 1850s, and even faster in the 1860s. However, these rates are likely to greatly exaggerate the rate of growth of quality-adjusted land, due to the fact that most of these years were dominated by squatter settlement (those who used Crown Land but never bought it). In fact, the earliest squatters settled on the best land as judged by distance from major ports of export (wool, Australia's main export, had to be carted to port by bullock and wagon over rough terrain); by-rainfall and water accessibility (Australia had a dry climate then as now); and thus by grass yield and sheep load per acre. While the acreage figures in Table 1 overstate quality-adjusted land growth ${ }^{30}$ there is no doubt about the fact that land endowments grew very fast across the halfcentury, faster than in the US. ${ }^{31}$ However, as any distributional inference must be guided by relative scarcity or abundance, we compare land expansion with both farm and total labour force growth. (18)

Between 1828 and 1850, the labour force is taken as the sum of male and female convict and free

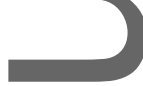

\footnotetext{
${ }^{26}$ See the data appendix for more details on how the acreage data have been constructed.

${ }^{27}$ The sourees we consulted did not provide a breakdown of pastoral land between pastoral leases, privately owned land used for pastures and waste land.

${ }^{28}$ Dye and La Croix, 'Political economy', p. 902.

${ }^{29}$ Roberts, Australian land settlement; Butlin, Colonial economy; Madsen, 'Australian economic growth'.

${ }^{30}$ Future research could explore land quality trends by hedonic adjustments based on distance to wool market, rainfall, and sheep load per acre, but we have not made the attempt here.

${ }^{31}$ US western settlement between 1800 and 1860 was driven much more by cultivation than by pastoral activity, and the major commodity exports were grain and cotton, not beef, hides or wool.
}

This article is protected by copyright. All rights reserved. 
labour reconstructed by combining data reported by Noel Butlin et al. and Glenn Withers and Len Perry. ${ }^{32}$ From 1851 onwards, we use male and female free labour data from the colonial censuses. The agricultural labour force estimates rely on the information reported in the colonial censuses on the share of those employed in the farm sector. ${ }^{33}$

As we can see from Table 1, farm labour grew at per annum rates of 6.5 per cent from 1828 to $1839,5.4$ per cent in the $1840 \mathrm{~s}$ and $1850 \mathrm{~s}$, but fell during the post-gold rush in the $1860 \mathrm{~s}$. Bearing in mind again the unmeasured decline in land quality, the ratio of acreage $(A)$ to farm labour $(L a)$ rose by 1.7 per cent per annum between 1828 and 1871. After an initial decline, the ratio of acreage to the total labour force $(L)$, soared by a whopping 10.4 per cent per year between 1860 and 1871 . All of this implies, of course, greater labour scarcity and land abundance; and relative land abundance was probably eyen greater, considering our conservative acreage estimates. But does it also imply a levelling of incomes between classes? The answer depends on trends in the gap between factor income shares. Indeed, the relevant comparison is between average annual earnings per worker $(w)$ and average annual rental income per landowner plus squatter (not per acre). In other words, rental income accruing to landed interests $(r A)$ compared with that accruing to unskilled workers $(r A / w L)=$ $(r / w)(A / L)$. As we have seen, $A / L$ soared, but greater labour scarcity implies that $r / w$ fell. Was the fall enough to lower $r A / w L$ and also $r A / Y$ ?

[Table 1 about here]

As we shall elaborate below in section $\mathrm{V}$, empirical progress on these questions is confronted by two data problems. First, land rent series are not available for any colony during these early decades. However, we can derive an estimate of land rents per acre $(r)$ by drawing on land values per acre $(v)$ estimates, given the interest rate $(i)$ and under the assumption that land values or land prices are simply the capitalized value of rents $(v=r / i){ }^{34}$ Second, the quality of the land value evidence is

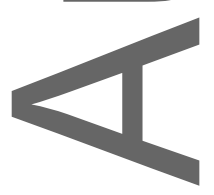

\footnotetext{
${ }^{32}$ Noel Butlin et al., 'Colonial statistics'; G. Withers and L. Perry, 'Australian historical statistics: labour statistics', Australian National University Source Papers in Economic History No 7 (1985).

${ }^{33}$ Refer to the online data appendix for details on how the labour force variables have been constructed.

${ }^{34}$ Data on interest rates are reported in Figure 1.
} 
much debated. ${ }^{35}$ Land values were determined by market forces since Crown Lands were auctioned off by colonial authorities. However, it should be stressed that Crown land sales were a major source of colonial government revenue. State involvement in the transactions (e.g. the timing of sales, parcel locations and their quality as well as the terms of the sales) may have distorted the average market price of land. ${ }^{36}$ Moreover, while squatters did not purchase their land at these Crown land sales, at least initialty, we have no other option but to assume that the market value of farm and pastoral land was the same as the prices recorded at Crown Land sales. Another difficulty arises from the fact that these sales deseribed the value per acre of new land (a flow), not the average value of all land sold, new and old (a steck). This is problematic as levels and even trends of stock and flow land prices may have diverged during this half-century. If the new land was of poorer quality and more distant from ports than the old land sold previously, it would fetch lower prices than the average in a stock dominated by previous sales of better land. ${ }^{37}$ If true, then the reported (new) land values per acre in Table 2 would, if quality adjusted, have a less steep downward trend than the (unknown) average land values (new and old). Unfortunately, we have no hedonic measures of land quality, like distance from

ports and rainfall, to make those adjustments. However, and as we also noted above, the vast majority of total reported acreage was being used by squatters that had rushed to the New South Wales interior after the Blue Mountains were breached in 1815. Since it was in the interests of the squatter to get to the best land before others, it seems likely that squatted land fell in quality over time, and since squatted land dominated total land, we think the land value estimates in Table 2 overstate the rise in land values $v$, and thus rents and incomes of the landed rich. In any case, we have no choice but to use the unadjusted Crown Land sales quotes in what follows. ${ }^{38}$

${ }^{35}$ A. M. Taylor, 'The value of land in Australia before 1913', Source Paper in Economic History 19, Australian National University (Canberra, 1992).

${ }^{36}$ We have no way of making an empirical assessment for the early decades, but for later years, see Taylor, 'Land in Australia'

${ }^{37}$ Taylor, 'Land in Australia', reports detailed evidence on land values per acre implied by Crown Land sales and those implied by local government tax assessments. The correlation between them is very poor. However, the tax assessment data for Victoria (starting 1865), New South Wales (starting 1883), Queensland (starting 1881) and South Australia (starting 1862) are all well beyond our half-century range. Since few local governments were given the authority to tax until beyond our period, we do not have that evidence to explore the quality of Crown Land sales data (for our purpose) during the dramatic pre-1870s growth decades.

${ }^{38}$ As suggested by an anonymous referee, the gradual shift between 1820 and 1870 from land sales dominated by Crown Land auctions to those dominated by commercial market sales adds further uncertainty to the
}

This article is protected by copyright. All rights reserved. 
We begin our analysis by noting the immense volatility in the land prices per acre (in $£$ ) reported in Table 2, driven, as we shall see below, by the volatility in world wool prices, supply-side climate shocks, and the speculation they both provoked. To minimize the impact of this volatility on trends, we take fiye-year averages at beginning and end. Between 1828-32 and 1856-60, land values per acre $(v)$ rose at 2.2 per cent per annum but land rents $(r)$ fell by 0.3 per cent per annum: this difference was likely to have been driven by the fall in interest rates (as discussed in section II). Furthermore, both rents and land values per acre fell across the 1860 s, after the gold rush of the previous decade-Moreover, the droughts of 1864-66 and 1868 in all the colonies except Tasmania, were also likely to have contributed to the decline in land values. In contrast, annual earnings of unskilled labour $(w)$ soared upward over the full half-century, pushing the wage-rental rate steeply upwards: between 1828 and $1860, w / v$ rose by 2.4 per cent per annum and $w / r$ by 2.5 per cent per annum. Across the $1860 \mathrm{~s}$, the figures were even higher, 5.4 and 6.6 per cent per annum, respectively.

[Table 2 about here]

Another way of looking at the impact of land settlement on inequality is by exploring trends in the ratio of land values per acre to gross domestic product per worker. Table 3 documents those trends, and the implications are clear. Land values per acre (v) grew much more slowly than GDP per worker (y) $y / v$ rose by 2.41 times, implying that inequality did not rise, but fell. ${ }^{39}$

[Table 3 about here]

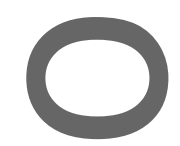

Land values per acre $(v)$ are the capitalized value of land rents $(r)$, or of land's marginal value product, where that marginal product is valued by prices of the commodity produced, here wool $(P w)$. Although the relation between rents and land values must have been influenced by expectations and speculation in the short run (Butlin and Barnard, 'Pastoral Finance', Table 1, p. 388), in the long run $v$ $=r / i$, where $i$ is the relevant bank interest rate facing sheep owners between shearing seasons.

accuracy of our land value series. Unfortunately, we are unable to assess whether this change introduced some bias to our estimated trends in land prices.

${ }^{39}$ It appears that this downward trend in $\mathrm{v} / \mathrm{w}$ turned around after the 1860 s when it rose steeply to about 1905 (Leigh Battlers and billionaires, Figure 3, p. 27).

This article is protected by copyright. All rights reserved. 
Therefore, the behaviour of the interest rate facing Australian pastoralists and farmers over time is informative of changes in land rents. If interest rates declined over the half-century before 1871, that must have put upward pressure on land values, such that any downward trend in rents would have been understated by trends in land values. This would also create a downward bias to any inferred distributional drift in incomes away from landowners and squatters and towards labour.

(

Figure 1 reports a fall in the Australian bank lending rate (loans for three months or more) [Figure 1 about here]

from a 10 per cent average in 1820-24 to a 7 per cent average in 1867-71. Furthermore, much of that 3 percentage point decline appears to have been driven by the integration of Australian with British capital markets, much like what was happening the world around over that half-century. ${ }^{40}$ That is, the gap between the higher Australian bank rate and the lower British consol rate fell from 6.2 per cent in 1820-24 to 3.9 per cent in $1867-71$, or by 2.3 percentage points (more than two-thirds of the fall in the Australian rate). After looking at the trends in the wedge between domestic and British interest rates, we also formally test for co-integration between the two series, using the Johansen cointegration test. ${ }^{41}$ The results support the existence of one co-integrating relation, that is of a long-run equilibrium between the two interest rates. ${ }^{42}$ While not an impressive rate of convergence towards integrated world financial markets, this is consistent with a recent literature that points to the second half of the nineteenth century, not the first, as the source of fast financial capital market integration. ${ }^{43}$

To summarize, land values per acre fell at a slightly slower rate than land rents per acre between 1828-32 and 1867-71 (Table 2) simply because interest rates fell as Australian and British capital markets (only partially) integrated. Still, these global financial market integrating forces were

${ }^{40}$ Lindert and Williamson, Unequal gains, pp. 134-5; Obstfeld and Taylor, 'Globalization'; eisdem, Capital markets; Mauro et al. Emerging markets.

${ }^{41}$ Johansen, Likelihood-based inference.

${ }^{42}$ We use one lag in the co-integration test, following Akaike's information criterion. When computing the parameters of the co-integrating equation using an error correction model, we find some weak evidence of price pass through.

${ }^{43}$ The rate of financial integration between Australia and Britain 1821-1871 may seem modest, but it is what the literature would have predicted. Obstfeld and Taylor, 'Globalization' and Capital markets, and Mauro et al., Emerging markets, argue that the biggest world financial market integration took place after 1870, although the United States, as a member of the leading North Atlantic 'global' economy, was the first and earliest to so integrate with Europe (Sylla et al., 'Integration').

This article is protected by copyright. All rights reserved. 
much too modest to have had a significant impact on the behaviour of Australian land values and thus wealth.

As-we have seen above, the ratio of land rents per acre to average annual earnings per unskilled worker $(r / w)$ and land values per acre to average annual earnings per unskilled worker $(v / w)$ fell dramatically between the 1820 s and the 1870 s (Table 2). Here, we explore the role played by the price of wool in driving the relative value of land and rents per acre downwards. If wool prices rose, then the decline in land values and rents per acre would be all the more surprising.

The economic impact of global events on commodity prices during the half-century before the 1870 s was carried by five global forces: $:^{44}$ a world transport revolution lowering the cost of moving goods between home and foreign markets, thus raising commodity export prices and lowering manufactured import prices in peripheral locations like Australia; ${ }^{45}$ a liberal trade policy move in Europe and its colonies (free trade in the British case), again serving to raise export prices in the exporter's markets; an acceleration in GDP and GDP per capita growth in Europe and North America, raising demand for all traded goods; an even greater acceleration in the demand for intermediates to (2) fuel rapid manufacturing growth in foreign markets; and resource 'discoveries' at the frontier. The first four of these worked to push upward the terms of trade in all resource abundant commodity exporting economies, raising their export prices and lowering the prices of their manufactured imports.

The impact was spectacular. The terms of trade in the periphery soared up to the late $1880 \mathrm{~s}$ and early 1890 s, paused at its peak, and then underwent the interwar collapse, which extended to the Korean War, an episode about which so much has been written. ${ }^{46}$ But between 1800 and 1870, the r. terms of trade in the commodity exporting periphery increased by almost two and a half times, or at an annual rate of 1.5 per cent. ${ }^{47}$

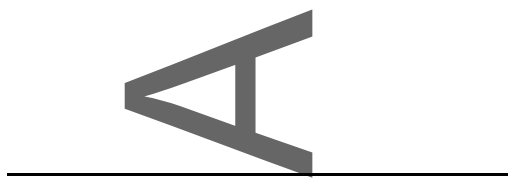

\footnotetext{
${ }^{44}$ Williamson, Trade and poverty, ch. 2.

${ }^{45}$ It must be said, however, that freight rates on shipping wool Melbourne or Sydney to London fell very little from 1845 to 1871 (Barnard, Australian wool market, tables XXI and XXII, pp. 225-6).

${ }^{46}$ Prebisch, Economic development; Singer, 'Distribution of gains'; Lewis, Evolution; idem, 'Engine of growth'.

${ }^{47}$ Williamson, Trade and poverty, ch. 3.
}

This article is protected by copyright. All rights reserved. 
What about the fifth dramatic global force, resource 'discovery'? Here is where commodity exporters around the periphery differed: some claimed only a small share of world supply of their commodity export (e.g. Egyptian cotton, Ottoman raisins, Philippine tobacco) and some a very large share (e.g. Chilean copper, Brazilian coffee, Indian jute). Those with small shares took their export prices as exogenous. Those with large shares influenced world prices by their own supply. It did not take Australia long to become the world's dominant wool supplier after the penetration of the Blue Mountains in 1815 and the opening up of the vast pastoral interior, after which acreage grew at about 6.5 per centper annum up to 1839 , a rate that doubled across the $1840 \mathrm{~s}$ and $1850 \mathrm{~s}$, and rose even more thereafter (Table 1). By 1850, British imports of Australian wool exceeded that of all other suppliers combined. ${ }^{48}$ Did world demand or Australian supply win the race? Table 4 supplies the answer. Relative to the GDP price deflator $(P w / P y)$, wool prices rose to a modest peak in the late 1840 s and early 1850 s, up by 36 per cent between $1828-32$ and $1845-52$, a 2 per cent per annum growth rate. But the boom did not last since $P w / P y$ then settled back to the 1828-32 levels in the following two decades. In short, there is no evidence of a secular wool price boom across the halfcentury before 1871, much unlike the experience of the typical commodity exporter at that time. Thus, the long run race between Australian wool supply and world demand was a tie, and the secular decline in $r / w$ or $v / w$ cannot be explained by some secular wool price slump.

[Table 4 about here]

Volatility, however, is another matter entirely. Indeed, the volatility of both $P w / P y$ and $r / w$ was immense, as illustrated in Figure 2. Here volatility is measured using the Hodrick-Prescott filter, which calculates how prices deviate from the trend. This volatility was something that all commodity exporters shared, ${ }^{49}$ even Australia from Federation to the present. ${ }^{50}$ Nineteenth century wool prices were no exception. ${ }^{1}$ Australia's wool price volatility was even more impressive when compared to other countries, both industrialized economies and commodity producers: it was 1.4 times bigger than that of the European periphery and the Middle East; 1.3 times bigger than Latin America; 1.5 times

\footnotetext{
${ }^{48}$ Barnard, Australian wool market, p. 20; Table VI, p. 218.

${ }^{49}$ Williamson, 'Great Divergence'; idem, 'Commodity prices'.

${ }^{50}$ Bhattacharyya and Williamson 'Commodity price shocks'; eisdem, 'Distributional consequences'.

${ }^{51}$ Weisser, 'Wool prices'.
} 
bigger than South and South East Asia; and 3.9 times bigger than the European colonizing 'core' (including Britain) during the first wave of globalization. ${ }^{52}$ And commodity price volatility has always had its impact on income distribution, the income shares accruing to those owning and/or exploiting the resources, like Australian squatters, landowners, and capitalists financing them during our halfcentury, or mining interests during the gold rush and over the next 150 years. We shall see the important influence of this volatility in Table 8 below where we document short run changes in the functional distribution of income across our half-century. ${ }^{53}$
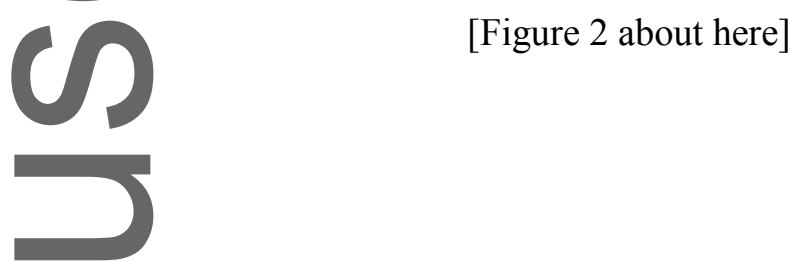

III

What were the labour market conditions under which this settlement process took place? ${ }^{54}$ In 1830 , male convicts and ex-convicts were about 88 per cent of the Australian male labour force and female convicts and ex-convicts were 55 per cent of the female labour force.$^{55}$ Of course, ex-convicts were

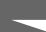

indistinguishable from originally-free labour, so the convict worker shares were lower, but still very large: 55 per cent of the total labour force in 1825 , and 40 per cent in $1840 .{ }^{56}$ It is what was called the 'assigned' convict that concerns us here: in 1827,72 per cent were assigned to private sector employers (called 'masters'), and in 1835 the figure was 66 per cent. ${ }^{57}$ The rest of the convicts were employed on public works (paid much like those assigned) or incarcerated. The assignment system was intended to reduce labour scarcity in the fast-growing private sector and to lower the financial

\footnotetext{
${ }^{52}$ See Wiltiamson, Trade and poverty, pp. 174-5 (Table 10.2), for a comparison with volatility in other economies.

${ }^{53}$ Wool price volatility may help account for high and rising land concentration among land owners (Leigh, Battlers and billionaires; Thomas, 'Evolution of inequality'). In frontier Australia, those who were able to take early advantage of such volatility established themselves quickly when wool prices rose thus becoming wealthy. For example, this is what seems to have happened in South Australia in the 1840s and 1850s, when high and rising wool prices allowed pastoralists who had either not paid for their land, or who were leasing, to buy their properties outright (Williams, Way of life). We are grateful to an anonymous referee for this suggestion.

${ }^{54}$ In our opinion, the most detailed and comprehensive description of the convict assignment system in Australia from the 1820 s to the 1850 s is that by Coghlan, Labour and industry, vol. 1, ch. II, pp. 173-99.

${ }^{55}$ Butlin, Colonial economy, p. 40.

${ }^{56}$ Meredith and Oxley, 'Convict economy', p. 114.

${ }^{57}$ Coghlan, Labour and industry, vol. 1, pp. 180-1.
}

This article is protected by copyright. All rights reserved. 
burden on the colonial purse. ${ }^{58}$ The system assigned convicts to work for private sector masters in all occupations, but farm and urban common labour dominated. The colonial government published requirements about 'payments' under the system overseen by magistrates: such information allows us to assess the amount of the marginal product that convicts were able to retain for their own consumption and to compare their 'earnings' with those of free labour. ${ }^{59}$ Estimating the gap between convict and free labour pay enables us also to gauge the extent to which cheap labour subsidies inflated the rents received by landed interests and the profits received by urban capitalists who employed them. ${ }^{60}$ And it will also allow us to assess its contribution to what we think was an immense levelling of ineones as the convicts were 'emancipated'.

The masters were required to support their convict servants with food (rations), lodging, clothing and ineidentals. In addition, the convict could earn additional income by hiring out for wages after assignment hours (3pm). These cash payments ranged from $£ 10$ to $£ 15$ per annum. ${ }^{61}$ However, cash payments for 'overtime' were only common for skilled mechanics and domestics. For others, the payment was made in additional rations (tea, sugar, rum), clothing and incidentals.

In order to estimate convict 'earnings', we reconstructed their yearly consumption of food, clothing, and incidentals as reported in Coghlan. ${ }^{62}$ We then priced the convict's consumption basket and added extra income from overtime work. As we have explained in detail elsewhere, convicts were paid only 59 per cent of the earnings received by free labour for the same work. ${ }^{63}$ This calculation refers to the 1830s, but we assume it remained much the same up to 1850.

Table 5 reports the convict 'exploitation' rate in the agricultural sector, namely the size of convicts' foregone earnings to subsidize their masters' income. This is calculated as the gap between (1)

\footnotetext{
${ }^{58}$ Coghlan, Labour and Industry, vol. 1, pt. II, ch. II; Butlin, Colonial economy, pp. 46-55; Meredith and Oxley, 'Convict economy'.1821 marks the colonial government's determination to give priority to the private (over public) employment of convicts.

59 Panza and Williamson, 'Australian exceptionalism'.

${ }^{60}$ The New South Wales assignment system officially ended in 1838-39, but persisted much longer. In Tasmania, a similar system ended only in 1857 (Meredith and Oxley, 'Contracting Convicts').

${ }^{61}$ Coghlan, Labour and Industry, vol. 1: p. 60.

${ }^{62}$ Coghlan, Labour and Industry, vol. 1: p. 182-3.

${ }^{63}$ Panza and Williamson, 'Australian exceptionalism'. The figure was even lower for skilled work since the inkind consumption remained the same, but the free labourer's earnings were much higher for skilled work in, say, the building trades or as a clerk. It was also much lower than $59 \%$ to the extent that after-3pm work was not available.
}

This article is protected by copyright. All rights reserved. 
free and convict wages, $w f-w c$, multiplied by convict labour force in agriculture, $L c a$, over total land rents, $r A .{ }^{64}$ Our estimates are certainly consistent with the claim that the assignment system greatly subsidized landowners, especially those operating large sheep walks, and especially the squatters who were the main source of the post-1815 pastoral boom: 'One of the primary factors in explaining the vulnerability of the squatters ... was the demise of the assignment system, and the consequent end of cheap labour ...65 Indeed, Table 5 estimates that in 1828-32 the convict cheap labour subsidy doubled the land rental share from 17.5 per cent to 34.7 per cent in New South Wales, a huge sum which had evaporated by $1851 .^{66}$ And that is not all. About half of the convicts were assigned to farm work, and the other half to urban work, thus also raising the profits of capitalists in urban areas.

The system also implied an unequal earnings distribution in the early decades of our halfcentury and a big erosion of that earnings inequality by the later decades. In 1828-32, the bottom of the distribution - the cheap coerced convicts - held about 18 per cent of total NSW income. By 1851 , the 'emancipated' convicts had moved up the earnings ranks, almost doubling their incomes if they remained unskilled, and moving up even higher if they could now exploit skills they could not exploit before, or could before only exploit at cheap unskilled labour rates.

[Table 5 about here]

The end of the convict transportation system coincided with another major shock to the Australian economy: the gold rush of the 1850s. It changed dramatically Australian demography. The population more than tripled between 1851 and 1871, the immigrants had a higher share female, and the immigrants' skills were relatively high with a large portion of professionals, technical craftsmen, clerks, managers and others. ${ }^{67}$ This influx served to stifle any rise in the skill premium as skill growth

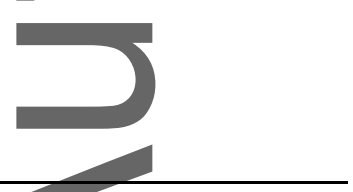

\footnotetext{
${ }^{64}$ We assume that convict and free labour were equally productive, as productivity varied across skill and educational attainment both among convicts and free (Nicholas, Convict workers, p.117). Furthermore, anthropometric data confirm that transported convicts had similar heights to British and Irish workers (Nicholas, Convict workers, pp. 78-80).

${ }^{65}$ Thomas, 'Evolution of inequality', p. 160.

${ }^{66}$ This is a lower bound. After all, free labour had to compete with cheap convict labour, thus lowering their wages as well.

${ }^{67}$ Withers, 'Immigration'.
}

This article is protected by copyright. All rights reserved. 
easily kept up with the modest demand growth. Hence, it did not lead to rising wage inequality, as we show below. ${ }^{68}$

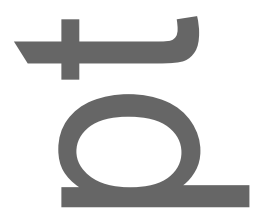

British colonial policy during the decades before the 1870s was dominated by Edward Gibbon Wakefield's thinking:

Wakefield's theory rested upon an understanding of the necessary social ... conditions for [a] capitalist/bourgeois society to prosper [reflecting] the liberal view of ... capitalism and democracy over the old order of privilege and corruption. Wakefield's ... policy [was intended] to ensure an ordered class society. ${ }^{69}$

We take 'ordered' to mean a much more egalitarian and meritocratic society than the unequal and privileged one which existed in England. Were these policies effective? Trends in two inequality proxies we have constructed might be a good place to start our search.

Claudia Goldin and Lawrence Katz have shown that the skill premium - the reward for schooling, literacy, and numeracy - was driven by supply and demand in twentieth century America. ${ }^{70}$ When the supply of those skilled and schooled grew slowly and demand grew fast, the reward to scarcer skills went up and so did earnings inequality. When instead demand grew slower than supply, the skill premium fell and so did earnings inequality. Demand always seems to race ahead of supply during the early years of modern economic growth and thus we expect the skill premium to rise, earnings inequality to increase, thus following the upswing of some Kuznets Curve. This certainly was the case in the United States between 1800 and 1860 when inequality rose so steeply. ${ }^{71}$ Do we expect the same for young Australia? Perhaps not. After all, we associate the demand for skills with city and industrial growth, and Australia was certainly not undergoing any dramatic industrial

\footnotetext{
${ }^{68}$ Withers ('Immigration') provides a detailed account of the higher supply of skilled labour relative to demand in Australia, especially compared to North America.

${ }^{69}$ Lloyd, 'Analytical framework', p. 63.

${ }^{70}$ Goldin and Katz, Education and technology.

${ }^{71}$ Lindert and Williamson, Unequal gains, ch. 5.
}

This article is protected by copyright. All rights reserved. 
revolution before the 1870s: the manufacturing share of economy-wide GDP was a trivial 4 per cent in 1821 and was still only 9 per cent in $1871 .^{72}$ Furthermore, while Australia had higher levels of urbanization at the start, the share living in the top five cities - Sydney, Melbourne, Adelaide, Perth, and Brisbane - fell from 52 per cent in 1810, to 23 per cent in 1841, and remained stable up to 1871 (24 per cent). And while the share in towns equal to or greater than 2,500 in 1851 was 40 per cent in Australia and only 14 per cent in the US, the former fell to 37 per cent in 1871 while the latter rose to 26 per cent. ${ }^{3}$

White modern economists explore this issue across the whole skill and schooling income range, economichistorians have more limited evidence. Indeed, typically they have measured the premium by using the wage rates of skilled in the building trades - masons, carpenters, bricklayers, wheelwrights, smiths and such - relative to non-farm common labour. ${ }^{74}$ Such measures do not, however, speak to the value of schooling, literacy, and numeracy, but rather only to age and experience. Fortunately, the Australian Colonial Blue Books report white collar annual pay by occupation which arms us with better evidence, since they allow us to document the premium that literate and numerate white-collar employees got relative to illiterate and less numerate unskilled labour. We report here the behaviour between 1828 and 1867 of both the premium that white collar clerks and professionals got relative to the urban unskilled, and the conventionally measured skill premium, that is what skilled workers in the building trades received relative to urban common labour, using data from Coghlan on nominal daily earnings. ${ }^{75}$ Thus, our data speak to trends in the gaps between the top and bottom of the free labour earnings ranks, as well as between the middle and the bottom

Table 6 shows clearly that Australia was exceptional. First, mechanics, artisans, and other free skilled workers earned a much higher premium over male urban common free labour in 1828 (2.75

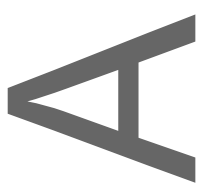

\footnotetext{
${ }^{72}$ Butlin et al., 'Statistical appendix', Table A1, pp. 556-7.

${ }^{73}$ Frost, 'Urbanisation', Tables 11.1 and 11.2, pp. 249, 250.

74 The tradition is perhaps best illustrated by Phelps-Brown, Century of pay.

${ }^{75}$ Coghlan, Labour and industry, vols. 1 and 2.
}

This article is protected by copyright. All rights reserved. 
times higher for carpenters in New South Wales) than in 1867 (1.57 times higher), a 43 per cent fall. ${ }^{76}$ This is also true when urban unskilled earnings are revised to include female domestics, as the skill premium fell by 41 per cent, almost exactly the same fall as when the unskilled are restricted to male common labour. ${ }^{77}$ This quantitative evidence is consistent with the qualitative literature which reports the complaints of employers and officials that skilled mechanics and artisans were hard to find in New South Wales and Tasmania in the first three decades of the nineteenth century ${ }^{78}$ So, no rising earnings inequality on that account. Second, the premium received by clerks relative to urban common labour fell over the half century, 5.86 in 1828 to 3.42 in 1867, a 58 per cent fall. Again, no evidence of rising earnings inequality. Third, and most telling, the premium received by top paid professionals - like surgeons, surveyors, judges and colonial officials - fell dramatically from 25.64 to 6.47 , a drop of 75 per cent. These skill premium trends suggest that earnings inequality (among free labourers) did not rise in the Australian colonies between the 1820 s and the 1870 s. Indeed, it appears to have fallen. ${ }^{79}$

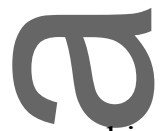

[Table 6 about here]

A second index of changing inequality compares trends in GDP per worker (the middle of the income distribution) with trends in the annual earnings of unskilled free labour (near the bottom of the income distribution). Our evidence in Table 7 covers New South Wales over the five decades from the 1830 s to the 1870 s, and it suggests that very little happened to the distribution of income in Australia during these years of wool boom and gold rush, despite the large migratory flows of free settlers. The average free non-farm unskilled labour earnings are constructed from Coghlan's work and refer to ${ }^{76}$ We are aware of only one other study that explores the mid-nineteenth century premium of mechanics over
common labour in Australia (Thomas, 'Evolution of inequality', figure 6.1, p. 168). While Thomas uses only pay
ratios between urban skilled working class and common labour, and for only for 1840 onwards, he also finds
no evidence of rising skill premiums.
77 The urban unskilled earnings series which includes female domestics is a weighted average of male and
female daily wages from Coghlan (Labour and industry, vols. 1 and 2 ), where the weights are based on labour
force participation rates by gender (from the censuses). Note that while the working class skill premium
decreased at much the same rate using either measure, the male/female urban unskilled wage ratio increased
by 45 per cent between 1828 and 1867 . Since the wages of women (e.g. domestics) were falling behind, it
served to raise earnings inequality. However, the female labour force share was much too small to influence
trends in total inequality.
78 Seltzer, 'Labour', p. 181 .
79 Our findings are in line with those of Pope and Withers ('Wage effects', p. 258), who find that the ratio of
skilled over unskilled wages fell in Australia between 1870 and 1914, in contrast to the American experience. 
New South Wales. ${ }^{80}$ The 'Australian' GDP figures are from Matthew Butlin and his collaborators when for the 1830s New South Wales included what became Victoria (in 1851) and Queensland (in 1859). ${ }^{81}$ We can deal with nominal or deflated figures, but those deflators require some discussion. The implicit price deflator for GDP is likely to rise much faster over time than the CPI for ordinary workers. Here is why. Our Coghlan-based CPI is dominated by commodities since services do not appear in workers' budgets (except for house rents). Those with higher incomes in the middle of the distribution had market baskets with higher proportions spent on services. Since services were labourintensive then, ${ }^{82}$ and since labour scarcity was on the rise in Australia, the GDP deflator should have risen much faster than the CPI for the unskilled. And so it did. The Coghlan commodity price data imply a fall in the CPI by 14.6 per cent between the 1830 s and 1870 s, while the GDP deflator rose by 7.2 per cent $^{83}$

In any case, real earnings of the unskilled rose by 2.5 to 2.7 times over the five decades while real GDP per worker rose by 2.5 times. No evidence of rising inequality by that account. While nominal GDP per worker rose faster than nominal unskilled earnings, 2.7 times versus 2.2 to 2.4 times, we think the deflated figures do a better job controlling for the likely bigger rise in the CPI for the middle income group than the CPI for those at or near the bottom. Once again, we see no evidence of rising earnings or income inequality.

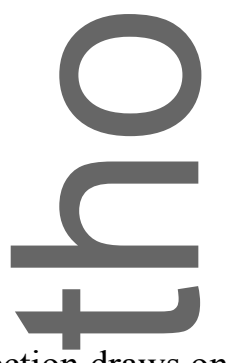

[Table 7 about here]

This section draws on the previous sections to construct annual estimates of the functional distribution of income across our half-century, thus speaking to Australian inequality experience leading up to the ${ }^{80}$ Coghlan, Labour and industry.

${ }^{82}$ Services loom large in GDP. In 1825, they were $46 \%$ of Australian GDP, and in 1865, the figure was $57 \%$ (Butlin et al., 'Statistical appendix', Table A1, pp. 556-7). Furthermore, much of it involves intermediates like government, transportation, utilities, retail trades, and wholesale trades. In contrast, nineteenth century working class budgets contained only house rents, haircuts, and the occasional funeral: perhaps only $15 \%$ of total expenditures.

${ }^{83}$ Butlin et al., 'Statistical appendix'.

This article is protected by copyright. All rights reserved. 
1870s. Table 8 documents the share of land rental income in GDP, $r A / Y$. Not surprisingly, the share was very high in the early years of this frontier economy. Between 1828 and 1832 , just fifteen years after the Blue Mountains were penetrated, the land rent share in New South Wales' GDP was 34.7 per cent, implying a yery unequal distribution of income. That income inequality was not necessarily translated into wealth inequality since so much of the pastoral land was squatted land, not owned land. ${ }^{84}$ Twenty years later (1848-52), the New South Wales share had plunged to 7.7 per cent, and it was lower still in 1860 , after the 1850s gold rush. The rental income share for all Australia remained fairly stable across the 1860s and early 1870s, around 2 per cent. A large part of the fall in the rental share was driven by rising labour scarcity $(r / w$ : Table 2$)$ and a good share of that rising labour scarcity was due to the disappearance of the huge subsidy offered by cheap coerced convict labour. ${ }^{85}$ But the share also fell as non-farm sectors grew faster than the farm sector: the agricultural employment share fell from a peak in $1841-45,49$ per cent, to 25.4 per cent in 1860 , a figure that was only a little lower across the 1860 s and early 1870 s (Table 1 ).

It seems clear that income was redistributed from the top to the bottom of the distribution across this half-century, and the levelling was massive. True, and as Thomas Piketty and others have argued, concentration among those at the top may not behave the same way as does income share accruing to all those at the top. ${ }^{86}$ Thus, Andrew Leigh has noted that 'In 1844, the top 0.1 per cent owned a whopping 17 per cent of the land and 11 per cent of the livestock, ${ }^{87}$ and earlier Mark Thomas documented the spectacular rise in land concentration between 1821 and $1838 .^{88}$ But those facts do not necessarily speak to overall income inequality. Indeed, like in Australia the property income share in the United States fell between 1800 and 1860 while wealth concentration rose among those receiving property income. ${ }^{89}$

[Table 8 about here]

\footnotetext{
${ }^{84}$ Of course, the squatters did own their sheep. We assume the land rents and prices reflected the value of sheep grazing on those acres.

${ }^{85}$ The subsidy is understated to the extent that cheap convict labour also pushed down the wage of free labour.

${ }^{86}$ Piketty, Capital.

${ }^{87}$ Leigh, Battlers and billionaires, p. 22.

${ }^{88}$ Thomas, 'Evolution of inequality', pp. 157-65

${ }^{89}$ Lindert and Williamson, Unequal gains, pp. 113-14.
} 
Although it is not reported in Table 8, the unskilled wages share can be easily calculated as the sum of the annual earnings accruing to unskilled free labour, $w f L f / Y$, that is, the average unskilled annual earnings $(w f)$ times the total free labour force $(L f)$ plus convict earnings $(w c L c / Y)$.

We start with the convicts at the bottom of the income distribution, whose share $(w c L c / Y)$ was a meagre 18 per cent in $1828-32 .^{90}$ Their share rose marginally with their numbers over the early years to a 19.9 per cent peak in $1840-4$, and then collapsed with gradual 'emancipation' to zero in 1851. What happened to the incomes of these 'emancipated' convicts? As they became free, they could (and did) move up the income ranks in three ways. First, they could join the free unskilled labour ranks as domestic servants, farm labour, or urban unskilled, jobs they had before but for which they only received 59 per cent (or even less) of free labour in the same jobs. In this, the most common case, they moved into the free unskilled category with incomes on average 41 per cent or more than previously, an income gain much higher than the upward income jump received by emancipated black slaves in the American South (about 30 per cent). ${ }^{91}$ Second, if they had the skills they could move up the earnings ranks as artisans, mechanics and skilled in the building trades, with incomes 3 to 4 times higher than their convict wages. Third, some with literacy and numeracy skills could become clerks and other white-collar employees, moving to the top of the earnings distribution. Not only did the convict share at the bottom of the income distribution disappear by 1851 , most stayed at the bottom of the free labour ranks where they doubled their incomes but many of those 'emancipated' convicts moved up the skill ladder. Both outcomes served to promote a pronounced levelling in the earnings distribution

The free unskilled labour share $(w f L f / Y)$ rose from 64.6 per cent during the convict era we can document (1828-49) to 70.2 per cent during a convict-free era at the end of our half-century (1861$71)$.

Estimating skilled labour's income share $([w s-w u s] L f s / Y)$ presents two problems, the solutions to which yield admittedly fragile estimates. Overall, we are more confident in estimated trends than levels. First, we need to measure the skill premium itself, and then we need to tally up those who were

\footnotetext{
${ }^{90} w c L c / Y$ represents the share of convicts' wage $(w c)$ times convicts' labour force $(L c)$ over GDP $(Y)$.

${ }^{91}$ Lindert and Williamson, Unequal gains, pp. 159-64.
} 
'skilled'. While our solutions to these two problems can certainly be challenged, we apply them consistently across our half century.

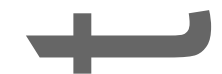

First, we approximate the skilled labour premium by taking the gap between clerks' annual earnings and that of urban common labour, ws-wus, based on the Colonial Blue Books: in New South Wales the ratio of the annual earnings of clerks to that of urban common labour fell from 5.86 in 1828 to 3.42 in 1871. A weighted average across a broader range of skills - including artisans at the bottom of the skilled earnings distribution, teachers in the middle, and doctors, judges, government officials and others at the white collar top - would be very difficult with the data currently available. By focusing on the skilled wage premium received by clerks, we probably understate the average skill premium to the extent that the excluded skilled above outnumber the excluded skilled below. However, we doubt that a broader skilled labour calculation would produce very different long-run trends in the income share, although it might well raise levels.

Second, we measure the skilled labour employment share as the total labour force minus farm workers, miners, domestics, and urban common labour divided by the total labour force. Our measure of skilled-occupations is an upper bound, including as it does carters, janitors, seamen and others, occupations which the 1828 census does not distinguish (although the 1871 census does). While our measure does document some economy-wide skilling across the half-century, it is surprising how modest it was. As defined, the share of the New South Wales labour force 'skilled' rose from 35.6 per cent at the 1828 census to 37.1 per cent at the 1871 census. This slow skilling rate is consistent with schooling evidence: from 1800 to 1870 , Australian average educational attainment grew at a snail's pace. ${ }^{92}$ Still, the stow growth in skill supply was enough to beat an even slower growth in demand, since the skill premium fell over the half-century.

With these two problems solved, we can proceed with estimating the skilled income share as the share of the labour force skilled times the skill premium, or one minus the ratio of the annual wage earnings of clerks relative to that of urban common labour. The results are presented in Table 8 . The

\footnotetext{
${ }^{92}$ Madsen, 'Australian economic growth', figure 2.5, p. 45.
} 
skill premium was a very small share of GDP in 1828-32, 1.3 per cent, and it fell to less than 1 per cent in 1856-60. It stayed almost the same in 1867-71. Clearly, the skill premium was not playing a significant role in explaining distributional changes across our half-century.

At the start of our half-century, Britain was committed to significant financial transfers to New South Wales and Tasmania (labelled $T / Y$ in Table 8). But what Noel Butlin called the 'legal fisc' had completely changed by the end of our half-century, or even earlier: by the end of the period, the colony (and private British capital) had assumed almost total responsibility for revenue and expenditure on goyernmental operations and infrastructure development. ${ }^{93}$ That is, local land, labour and capital were receiving external subsidies (a negative entry in Table 8) from Britain. The transfer took the form of Commissariat expenses related to the penal system, the Colonial Fund for policing, defence, and infrastructure, and Crown Land sales. The latter was a source of special tension between Britain and the colonists, each claiming the land and its sales revenue as theirs, Britain giving up its claim by the 1850 s. In any case, Table 8 enters these transfers as a negative: thus, without the transfer, all the other shares would have fallen) share of GDP based on Butlin's estimates, and those shares are very big early in our half-century: ${ }^{94}$ they were -25.07 per cent for $1828-32$, down to -10.79 per cent for 1846-50, and almost nothing thereafter. ${ }^{95}$

The residual claimants share in Table 8 belongs to capitalists. ${ }^{96}$ Furthermore, most of the large short run volatility of GDP ends up in the residual since we have no evidence with which to document short run unemployment or land rental (and mining) income booms and busts associated with that volatility. Still, here is what it implies for the long run: the residual share averaged about 24.7 per cent in the early years 1828-40, swelled to 40.8 per cent during the gold rush decade (1850-60), and dropped down to 27.2 per cent in the 1860 s (1861-71). Thus, the capitalist income share reveals only

\footnotetext{
${ }_{93}$ Butlin, Colonial economy, ch. 10.

${ }^{94}$ Butlin, Colonial economy, table 10.2, p. 87.

${ }^{95}$ Note that the slow disappearance of the initially large imperial transfer implies a fall in all shares up to 1850 , a bigger fall early and a smaller fall late. Thus, for example, without the British transfer in the calculation, the rental share drops from $28.1 \%$ in $1828-32$ (when the transfer was very big) to a much lower $9.02 \%$ in $1846-50$ (when the transfer was much smaller).

${ }_{96}^{96}$ Not quite. Since land rents does not include the returns to holding sheep and cattle, the residual does. We have not attempted to separate out property income embodied in these flocks and herds, but we doubt it would influence trends in the rental share or the residual.
}

This article is protected by copyright. All rights reserved. 
a modest upward trend over the half-century. However, we want to stress the great volatility in the share: for example, it was negative during two mid-convict years 1831-32, very low (3.9 per cent) during 1843 and 1844 at the bottom of the 1840s depression and very high during the gold rush 1850 s decade (40.9 per cent). Although less dramatic, that volatility is shared by land rents, and our discussion above about wool exports and prices predicted that volatility in both (a very common phenomenon for most commodity exporters). That volatility is also consistent with decadal booms and busts between 1800 and $1870 .^{97}$

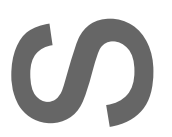

It appears that Australia has undergone two episodic egalitarian levelling over the past two centuries, both about a half-eentury in length. The first one, discussed here, covered the half-century from the 1820 s to the 1870 s. The second one, which occurred between the First World War and the 1970 s, ${ }^{98}$ was witnessed by most OECD countries, since they shared the same exogenous political and global shocks. ${ }^{99}$ The one discussed here was certainly not shared with Western Europe, or with their New World offshoots, especially not with the United States. We know now that the United States rode up a steep Kuznets Curve from an egalitarian British colony in 1774 to an unequal modern society in 1870 , thus joining an unequal Western European club. And the United States income distribution is pretty much the same today. Australia's experience is exceptional since, while its GDP grew at a high rate, the gains from such growth did not accrue disproportionately to a minority of squatters, landowners and capitalists at the top. Indeed, their combined share fell significantly: the land rent and residual capitalist share combined fell dramatically from 35.9 per cent $1828-32$ to 29.1 per cent in $1867-71$. In addition, remember that the convicts, 55 per cent of the labour force in the 1820 s, moved up the income ladder as they emancipated, doubling their incomes or more upon emancipation, and that there were no convicts by the 1870 s. Thus, Australia's income distribution moved in a direction opposite to that of the United States. Part of this exceptionalism was driven by the emancipation of coerced

\footnotetext{
${ }_{97}$ Madsen, 'Australian economic growth', figure 2.1, p. 31.

98 Leigh, Battlers and billionaires; Atkinson and Leigh, 'Top incomes'.

${ }^{99}$ Lindert and Williamson, Unequal gains, ch. 8.
}

This article is protected by copyright. All rights reserved. 
convicts and part of it was driven by the absence of the kind of early industrialization that overtook the United States.

It must be said, however, that the work reported here speaks better to trends than to levels. In the near future, we intend to answer two 'level' questions as well: In the 1870 s, how much more egalitarian was Australia than the United States and Western Europe? And was that difference pretty much like it is today? ${ }^{100}$

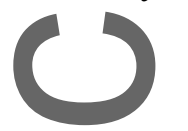

\section{Footnote references}

Alford, K., 'Colonial women's employment as seen by nineteenth-century statisticians and twentiethcentury economic historians', Labour History, 51(1986), pp. 1-10.

Anderson, E., 'Globalisation and wage inequality, 1870-1970', European Review of Economic History, 5 (2001), pp. 91-118.

Atkinson, A. B. and Leigh, A., 'The distribution of top incomes in five Anglo-Saxon countries over the long run', Economic Record, 89 (S1) (2013), pp. 31-47.

Barnard, A., The Australian wool market 1840-1900 (Melbourne, 1958).

Bhattacharyya, S. and Williamson, J. G., 'Commodity price shocks and the Australian economy since federation', Australian Economic History Review, 51 (2011), pp. 150-77.

Bhattacharyya, S. and Williamson, J. G., 'Distributional consequences of commodity price shocks: Australia over a century', Review of Income and Wealth, 62 (2016), pp. 223-44.

Butlin, M., Dixon, R. and Lloyd, P. J., 'Statistical appendix: selected data series, 1800-2010', in S. Ville and G. Withers, eds., The Cambridge economic history of Australia (Cambridge, 2015), pp. 555-91.

Butlin, N. G., Our original aggression: Aboriginal populations of south-eastern Australia, 1788-1850 (Sydney, 1983).

Butlin, N. G., Forming a colonial economy: Australia 1810-1850 (Cambridge, 1994).

Butlin, N. G., and Barnard, A, 'Pastoral finance and capital requirements', in A. Barnard, ed., The simple fleece: studies in the Australian wool industry (Melbourne, 1962), pp. 383-400.

Butlin, N.G, Ginswick, J. and Statham, P., 'Colonial statistics before 1850', Source Papers in Economic History (Australian National University, Canberra, 1986).

\footnotetext{
${ }^{100}$ We intend to answer the 1870 s level question soon. The Colonial Blue Books, occupational Censuses and other sources make it possible to construct a social table for each colony, and thus the Australian earnings distribution for 1871, and perhaps even the income distribution.
}

This article is protected by copyright. All rights reserved. 
Butlin, N. G., Hall, A. R and White, R. C., Australian banking and monetary statistics. 1817-1945 (Sydney, 1971).

Coghlan, T. A., Labour and industry in Australia, from the first settlement in 1788 to the establishment of the Commonwealth in 1901, 3 vols. (Melbourne, 1918).

Dye, A., and La Croix, S., 'The political economy of land privatization in Argentina and Australia, 1810-1850: a puzzle', Journal of Economic History, 73 (2013), pp. 901-36.

Findlay, R. and O'Rourke, K. H., Power and plenty: trade, war, and the world economy in the second millehnium (Princeton, 2009).

Fitzgerald, S., Rising Damp: Sydney, 1870-90 (Melbourne and New York, 1987).

Fox, C., Working Australia (Sydney, 1991).

Frost, L., 'Urbanisation', in S. Ville and G. Withers, eds., The Cambridge economic history of Australia (Cambridge, 2015), pp. 245-65.

Goldin, C. and Katz, L., The race between education and technology (Cambridge, 2008).

Greasley, D., Madsen, J. B. and Oxley, D., 'Real wages in Australia and Canada, 1870-1913: globalisation versus productivity', Australian Economic History Review, 40 (2000), pp. 17898

Hunter, B., 'The aboriginal legacy', in S. Ville and G. Withers, eds., The Cambridge economic history of Australia (Cambridge, 2015 ), pp.73-96.

Hunter, B., and Carmody, J., 'Estimating the Aboriginal population in early colonial Australia: the role of chickenpox reconsidered', Australian Economic History Review, 55 (2015), pp. 112-38.

Johansen, S., Likelihood-based inference in cointegrated vector autoregressive models (Oxford, 1995)

Kingston, B. The Oxford history of Australia: glad, confident morning, vol. 3, 1860-1900 (South Melbourne, 2009).

Lee, J., and Fahey, C., 'A boom for whom? Some developments in the Australian labour market, 1870-1891', Labour History, 50 (1988), pp. 1-27.

Leigh, A., Battlers and billionaires: the story of inequality in Australia (Melbourne, 2013).

Lewis, W. A., The evolution of the international economic order (Princeton, 1978).

Lewis, W. A.,' The slowing down of the engine of growth', American Economic Review, 70 (1980), pp.

Lindert, P.H. and Williamson, J. G., Unequal gains: American growth and inequality since 1700 (Princeton, 2016).

Lloyd, C., 'Analytical framework of Australia's economic history', in S. Ville and G. Withers, eds., The Cambridge economic history of Australia (Cambridge, 2015), pp. 52-69.

This article is protected by copyright. All rights reserved. 
Madsen, J. B., 'Australian economic growth and its drivers since European settlement', in S. Ville and G. Withers, eds., The Cambridge economic history of Australia (Cambridge, 2015), pp. 29-51. Mauro, P., Sussman, N. and Yafeh, Y., Emerging markets and financial globalization (Oxford, 2006). McLean, I. W., Why Australia prospered: the shifting sources of economic growth (Princeton, 2012). Meredith D. and Oxley, D., 'Contracting convicts: the convict labour market in Van Diemen's Land 1840-1857', Australian Economic History Review, 45 (2005), pp. 45-72.

Meredith, D. and Oxley, D., 'The convict economy', in S. Ville and G. Withers, eds., The Cambridge economic history of Australia (Cambridge,2015), pp. 97-121.

Mulvaney, D. J., and Kamminga, J., Prehistory of Australia (1999).

Nicholas, S., Convict workers: reinterpreting Australia's past (Cambridge, 1988).

Obstfeld, M. and Taylor, A. M., 'Globalization and capital markets', in M. D. Bordo, A. M. Taylor and J. G. Williamson, eds., Globalization in historical perspective (Chicago, 2003), pp. 121-83.

Obstfeld, M. and Taylor, A. M., Global capital markets: integration, crisis and growth (Cambridge, 2004).

O'Rourke, K. H., Taylor, A. M. and Williamson, J. G., 'Factor price convergence in the late nineteenth century', International Economic Review, 37 (1996), pp.499-530.

O'Rourke, K.H. and Williamson, J. G., Globalization and history: the evolution of a nineteenth-century Atlantic economy (Cambridge, 2001).

Panza, L. and Williamson, J. G., “Australian exceptionalism? Inequality and living standards 18211871', CEPR Discussion Paper 11756 (2017).

Phelps-Brown, E. H., A century of pay: the course of pay and production in France, Germany, Sweden, the United Kingdom, and the United States of America, 1860-1960 (1968).

Piketty, T., Capital in the twenty- first century, trans. by A. Goldhammer (Cambridge, MA, 2014).

Prebisch, R., The economic development of Latin America and its principal problems (New York, 1950).

Pope, D. and Withers, G., 'Wage effects of immigration in late nineteenth century Australia', in T. J. Hatton and J. G. Williamson, eds., Migration and the international labour market, 1850-1939 (1994).

Roberts, S.H., History of Australian land settlement, 1788-1920 (Melbourne,1924).

Seltzer, A., 'Labour, skills and migration', in S. Ville and G. Withers, eds., The Cambridge economic history of Australia (Cambridge, 2015), pp. 178-201.

Shanahan, M. and Wilson, J. K., 'Measuring inequality trends in colonial Australia using factor-price ratios: the importance of boundaries', Australian Economic History Review, 47 (2007), pp. 621.

This article is protected by copyright. All rights reserved. 
Singer, H. W., 'The distribution of gains between investing and borrowing countries', American Economic Review, 40 (1950), pp. 473-85.

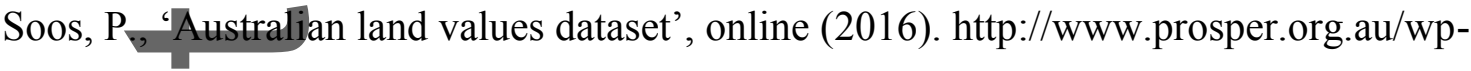
content/uploads/2013/05/Philip_Soos_Australian_Land_Value_Datasets_v2.pdf de Souza, C., and Nicholas, S., 'Height, health, and economic growth in Australia, 18604940', in R. H. Steckel and R. Floud, eds., Health and welfare during industrialization (Chicago, 1997), pp. 379-422.

Sylla, R. E.,Wilson, J. W. and Wright, R. E., 'Integration of trans-Atlantic capital markets, 1790-1845', Review of Finance, 10 (2006), pp. 613-44.

Taylor, A. M., 'The value of land in Australia before 1913', Source Paper in Economic History 19, Australian National University (Canberra, 1992).

Thomas, M., 'The evolution of inequality in Australia in the nineteenth century', in Y. S. Brenner and

H. Kaelble, eds., Income distribution in historical perspective (Cambridge, 1991), pp. 149-73.

Vamplew, W., Australians, historical statistics (Broadway, Australia, 1987).

Weisser, M., 'Stabilization of wool prices', A. Barnard, ed., The simple fleece: studies in the Australian wool industry (Melbourne, 1962), pp. 507-20.

Whitwell, G., de Souza, C. and Nicholas, S., 'Height, health, and economic growth in Australia, 18601940 , in R. H. Steckel and R. Floud, eds., Health and welfare during industrialization (Chicago, 1997), pp. 379-422.

Williams, E., A way of life: the pastoral families of the Central Hill Country of South Australia (Adelaide, 1980).

Williamson, J. G., 'Land, labor and globalization in the Third World 1870-1940', Journal of Economic History, 62 (2002), pp. 55-85.

Williamson, J.G., Globalization and the Great Divergence: terms of trade booms and volatility in the poor periphery 1782-1913', European Review of Economic History, 12 (2008), pp. 355-91.

Williamson, J. G., Trade and poverty: when the Third World fell behind (Cambridge, 2011).

Williamson,J. G., 'Commodity prices over two centuries: trends, volatility and impact', Annual Review of Resource Economics, 4 (2012), pp. 185-207.

Withers, G.,' 'The immigration contribution to human capital formation', in D. Pope and L. Alston, ustralia's greatest asset: human resources in the nineteenth and twentieth centuries (Sydney, 1989), pp. 53-71.

Withers, G., and Perry, L., 'Australian historical statistics: labour statistics', Australian National University Source Papers in Economic History No 7 (1985). 


\section{Official Publications}

House of Commons Sessional Papers: Statistical Tables relating to the Colonial and other Possessions

of the United Kingdom, Parts I-XVII (1856-1881). Command Papers No: 2127; 2284; 2441;

2565; 2741; 2893; 3065; 4194-I; 3396; 3650; 3879; 4030-I; 4194-I; C.1038; C.2029; C.2867;

C. 4519

New South Wales, Blue Book (Sydney, 1869).

Victoria, Blue Book of 1867 (Melbourne, 1868).

1841 census of New South Wales, Port Phillip District (Sydney, 1841).

New South Wales census of 1871: consisting of report, summary tables, and appendix and detailed tables (Sydney,1873).

Census of Victoria, 1871: general report and appendices (Melbourne, 1874).

Van Diemen's Land census 1842 (Hobart, 1842).

Census of the colony of Tasmania 1871 (Hobart, 1873).

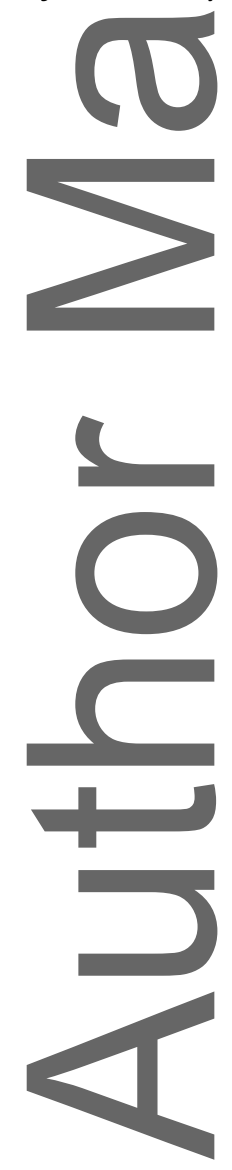

This article is protected by copyright. All rights reserved. 
Figure 1: Australian and British interest rates, 1820-1871

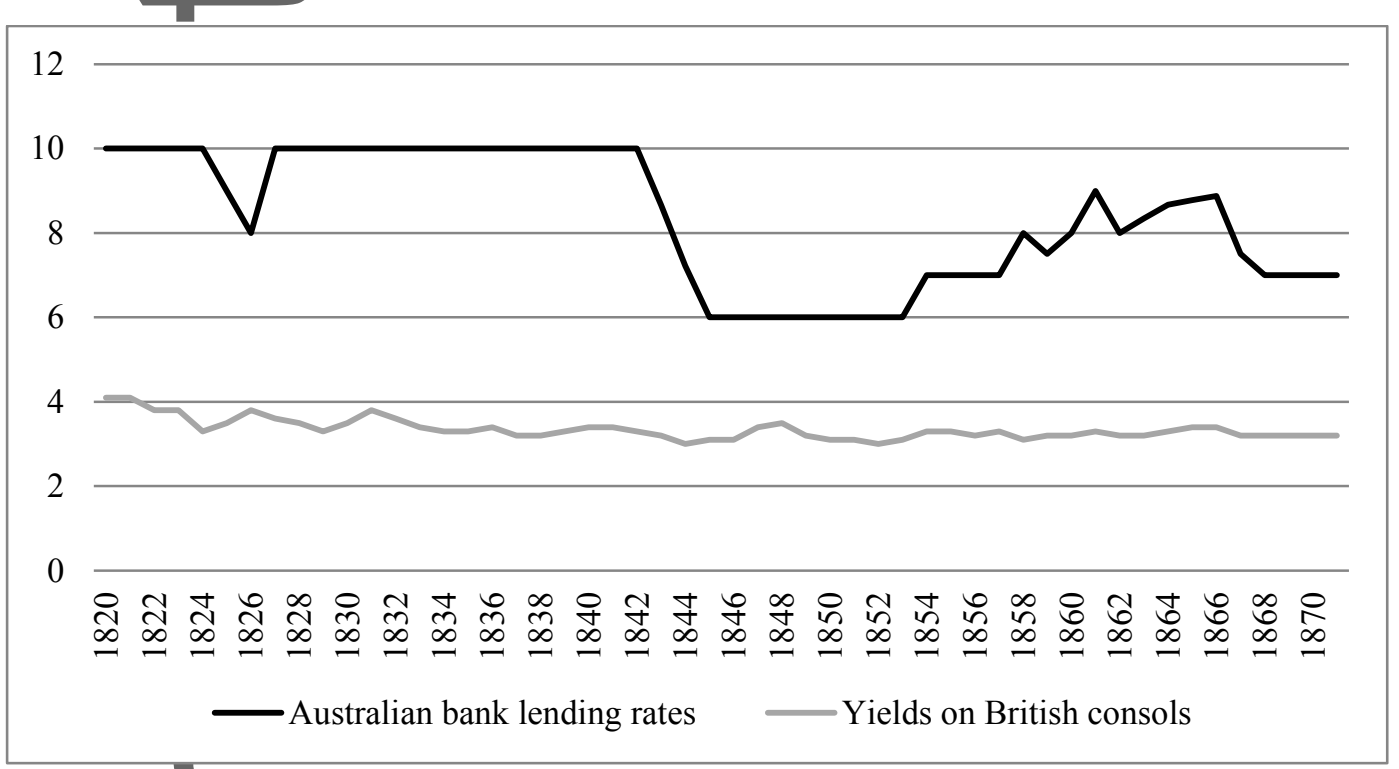

Sources: Australian Bank Lending Rates in \%, three months or more, are from N. Butlin et al., Australian banking with geometric interpolation. Yields on British Consols in \% are from N. Butlin et al., Australian banking.

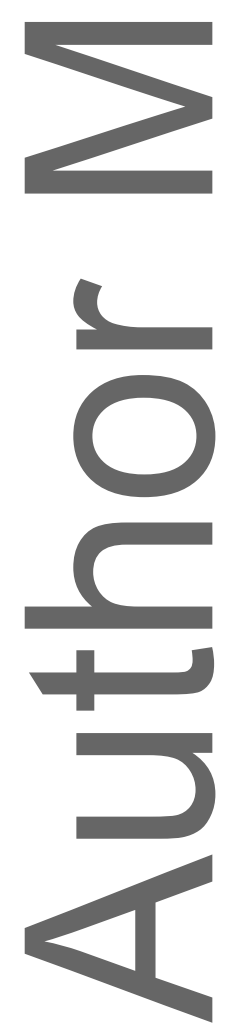


Figure 2: Volatility in the Rental/Wage Ratio $(r / w)$ and in Wool Prices Relative to the GDP Deflator $(P w / P y)$.

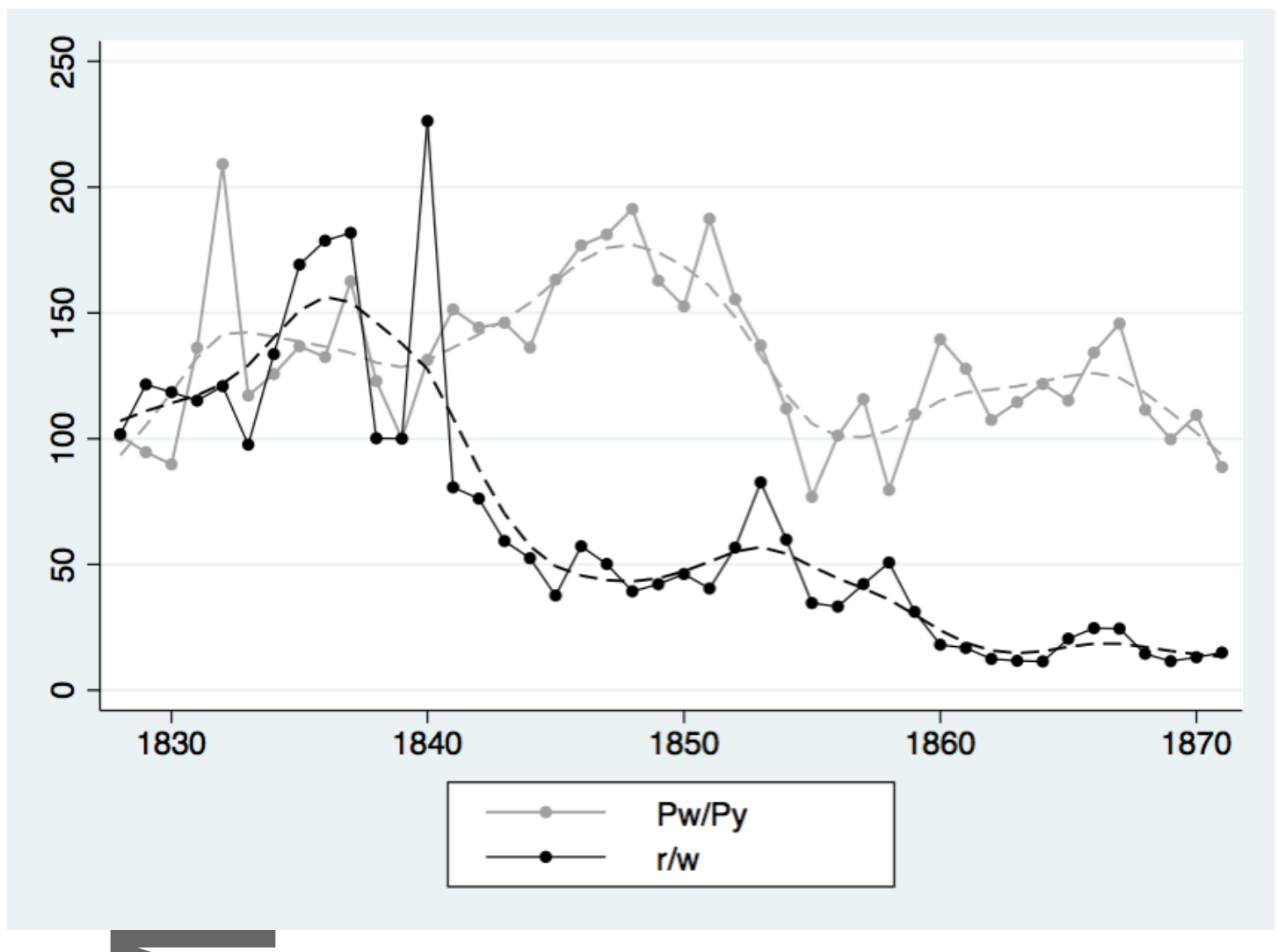

Sources: Rental/wage ratio: see Table 2. Relative wool prices: see Table 4.

Notes: The dashed lines represent the trend component of each series, calculated using the HodrickPrescott filter.

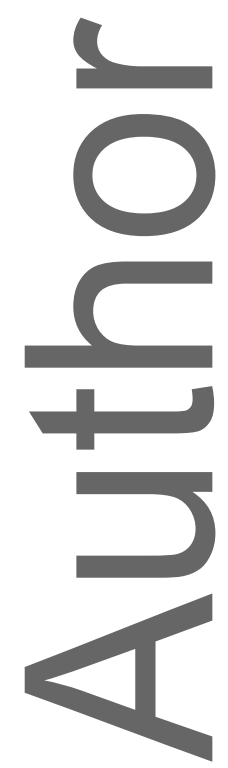


Table 1: Pastoral and cultivated acres, total and agricultural labour force $(1,000)$, $1828-1871$

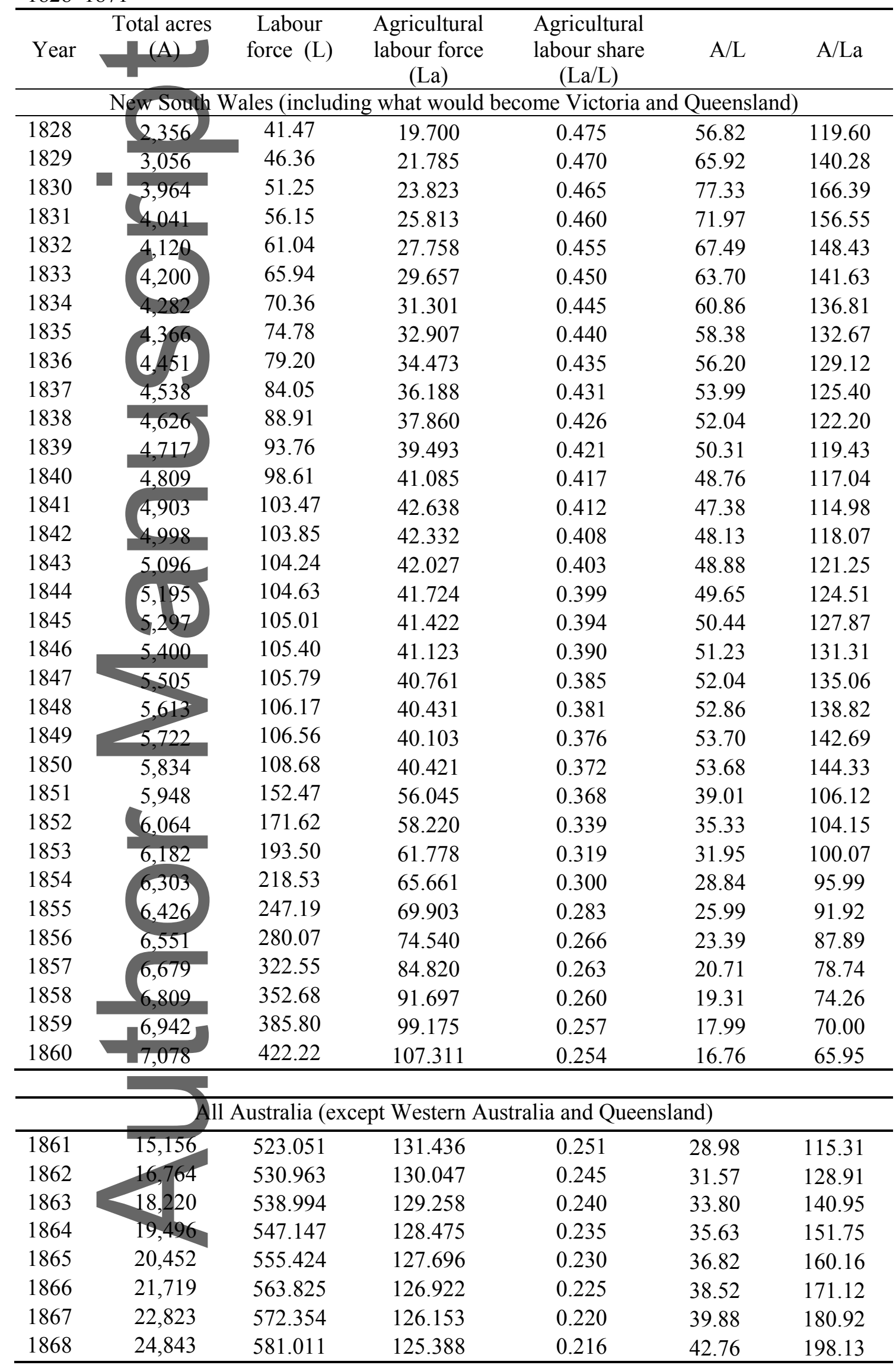

This article is protected by copyright. All rights reserved. 


\begin{tabular}{lllllll}
\hline 1869 & 25,673 & 589.800 & 124.628 & 0.211 & 43.53 & 206.00 \\
1870 & 28,182 & 598.722 & 123.873 & 0.207 & 47.07 & 227.51 \\
1871 & 30,143 & 607.778 & 123.122 & 0.203 & 49.59 & 244.82 \\
\hline
\end{tabular}

Sources. Total acres $(A)$ include pastures and crop land in New South Wales, Victoria, Tasmania, South Australia and Queensland. They are from N. Butlin et al., 'Colonial statistics'; Roberts, Australian land settlement, pp. 24, 81, 106; Vamplew, Australians; and House of Commons Sessional Papers. The total labour force $(L)$ is the sum of convict and free workers. Convict data are from Butlin et al., 'Colonial statistics', Table A3. Free data are from Withers and Perry, 'Historical statistics', Table D and from the colonial censuses accessed at http://hccda.ada.edu.au. Agricultural Labour Force $(L a)$ is derived from agricultural labour force shares from the colonial censuses. See the data appendix for details on how all the variables have been constructed.

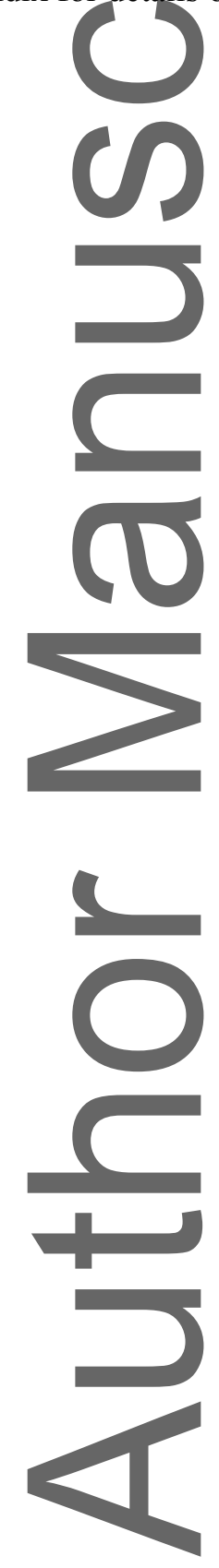

This article is protected by copyright. All rights reserved. 
Table 2: Land values, rents, and relative land-labour scarcity, 1828-1871

\begin{tabular}{|c|c|c|c|c|c|}
\hline Year & $\begin{array}{c}\text { Land values per } \\
\text { acre } £ \\
\text { (v) }\end{array}$ & $\begin{array}{l}\text { Land rents per } \\
\text { acre } £(r)\end{array}$ & $\begin{array}{l}\text { Unskilled labour average } \\
\text { annual earnings } £(w)\end{array}$ & $w / v$ & $w / r$ \\
\hline \multicolumn{6}{|c|}{ New South Wales (including what would become Victoria and Queensland) } \\
\hline 1828 & & 0.124 & 29.878 & 24.0 & 240.3 \\
\hline 1829 & & 0.149 & 29.961 & 20.1 & 201.1 \\
\hline 1830 & 1.455 & 0.145 & 30.027 & 20.6 & 206.4 \\
\hline 1831 & 1.416 & 0.142 & 30.082 & 21.2 & 212.4 \\
\hline 1832 & & 0.149 & 30.128 & 20.2 & 202.3 \\
\hline 1833 & & 0.120 & 30.166 & 25.0 & 250.4 \\
\hline 1834 & & 0.166 & 30.416 & 18.3 & 183.0 \\
\hline 1835 & & 0.212 & 30.633 & 14.5 & 144.5 \\
\hline 1836 & & 0.225 & 30.822 & 14.5 & 136.8 \\
\hline 1837 & & 0.235 & 31.603 & 15.2 & 134.5 \\
\hline 1838 & 1.101 & 0.132 & 32.258 & 29.3 & 244.1 \\
\hline 1839 & & 0.134 & 32.814 & 24.4 & 244.4 \\
\hline 1840 & & 0.330 & 35.698 & 13.0 & 108.1 \\
\hline 1841 & 1.164 & 0.128 & 38.835 & 33.3 & 303.2 \\
\hline 1842 & 1.316 & 0.132 & 42.248 & 32.1 & 321.1 \\
\hline 1843 & 1.288 & 0.112 & 45.961 & 35.7 & 412.1 \\
\hline 1844 & & 0.107 & 50.000 & 33.6 & 466.1 \\
\hline 1845 & & 0.081 & 52.421 & 39.0 & 649.7 \\
\hline 1846 & & 0.129 & 54.960 & 25.6 & 427.4 \\
\hline 1847 & & 0.118 & 57.621 & 29.2 & 487.5 \\
\hline 1848 & & 0.097 & 60.411 & 37.3 & 622.4 \\
\hline 1849 & & 0.109 & 63.336 & 34.8 & 580.3 \\
\hline 1850 & 2.089 & 0.125 & 66.403 & 31.8 & 529.7 \\
\hline 1851 & 1.919 & 0.115 & 69.619 & 36.3 & 604.6 \\
\hline 1852 & 2.820 & 0.169 & 72.990 & 25.9 & 431.4 \\
\hline 1853 & & 0.259 & 76.524 & 17.8 & 296.0 \\
\hline 1854 & & 0.196 & 80.230 & 24.5 & 408.6 \\
\hline 1855 & & 0.114 & 80.587 & 42.3 & 370.8 \\
\hline 1856 & & 0.110 & 80.945 & 44.1 & 400.9 \\
\hline 1857 & 2.337 & 0.140 & 81.305 & 34.8 & 248.0 \\
\hline 1858 & 2.823 & 0.169 & 81.667 & 28.9 & 170.8 \\
\hline 1859 & & 0.104 & 82.030 & 44.5 & 425.6 \\
\hline 1860 & & 0.061 & 82.395 & 54.1 & 888.0 \\
\hline \multicolumn{6}{|c|}{ All Australia except Western Australia and Queensland } \\
\hline 1861 & 1.419 & 0.057 & 82.761 & 58.3 & 1027.9 \\
\hline 1862 & 1.057 & 0.042 & 83.129 & 78.7 & 1860.9 \\
\hline 1863 & & 0.040 & 83.499 & 83.8 & 2100.9 \\
\hline 1864 & 0.980 & 0.039 & 83.870 & 85.6 & 2182.2 \\
\hline 1865 & 0.876 & 0.070 & 83.716 & 95.6 & 1364.9 \\
\hline 1866 & 0.929 & 0.084 & 83.562 & 90.0 & 1067.0 \\
\hline 1867 & 0.982 & 0.083 & 83.408 & 85.0 & 1018.1 \\
\hline 1868 & 1.058 & 0.049 & 83.255 & 78.7 & 1597.5 \\
\hline 1869 & 0.871 & 0.039 & 83.101 & 95.4 & 2433.5 \\
\hline
\end{tabular}

This article is protected by copyright. All rights reserved. 


\begin{tabular}{llllll}
\hline 1870 & 0.740 & 0.044 & 82.949 & 112.1 & 2523.0 \\
1871 & 0.843 & 0.051 & 82.796 & 98.2 & 1941.5 \\
\hline
\end{tabular}

Sources: Land values per acre (v) are Crown land average sales prices from Taylor, 'Land in Australia', and Soos, 'Land values'; 1828-1837 uses the only available Tasmania series; 1837-1865 uses an acreage-weighted average of the only available Victoria and South Australia series; and 18651879 uses an acreage-weighted average of New South Wales, Victoria, and South Australia. Land rents per acre $(r)=v / i$ where the interest rate series $(i)$ is bank lending rates in Figure 1. Unskilled average annual earnings $(w)$ are from Table 5.

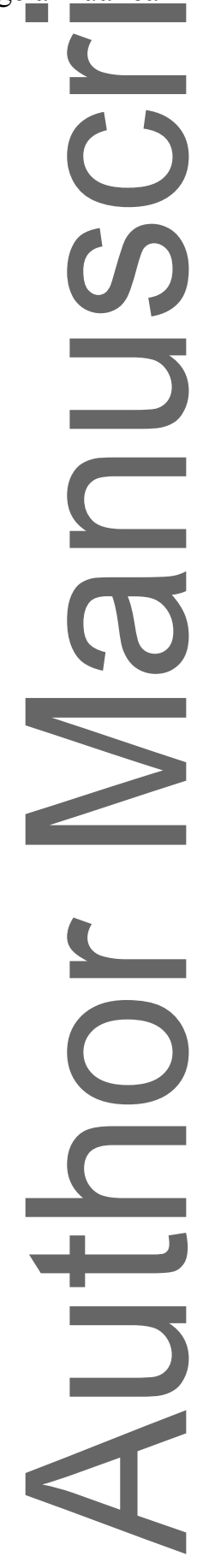


Table 3: Relative land values trends $1830 \mathrm{~s}-1870 \mathrm{~s}$

\begin{tabular}{lccccc}
\hline & $\begin{array}{c}\text { Annual earnings } \\
\text { common labour }(w)\end{array}$ & $\begin{array}{c}\text { GDP } \\
\text { perworker }(y)\end{array}$ & $\begin{array}{c}\text { Land values } \\
\text { per acre }(v)\end{array}$ & w/v & $y / r$ \\
\hline $1830 s$ & 100 & 100 & 100 & 100 & 100 \\
$1870 s$ & 237 & 270 & 112 & 212 & 241 \\
\hline
\end{tabular}

Sources: The land value data (v) are from Soos, 'Land values'. GDP data are from Butlin et al., 'Statistical appendix', Table A1, pp. 555-7, Table A2, pp.562-3. Total labour force data used to deflate nominal GDP are from colonial censuses. Unskilled average annual earnings $(w)$ are from Coghlan, Labour and industry, vol. 1.

Notes: Land values per acre are a weighted average of VIC \& SA. Annual urban common labour earnings are from NSW. The GDP figures are for 'Australia'.

Table 4: Wool price indices, nominal and relative 1828-1871 (1861=100)

\begin{tabular}{|c|c|c|c|}
\hline Year & $\begin{array}{l}\text { wool price index } \\
(P w)\end{array}$ & $\begin{array}{c}\text { GDP deflator } \\
(P y)\end{array}$ & $\begin{array}{l}\text { Relative wool price index } \\
(P w / P y)\end{array}$ \\
\hline 1828 & 76.9 & 97.4 & 79.0 \\
\hline 1829 & 71.2 & 96.1 & 74.0 \\
\hline 1830 & 53.8 & 76.6 & 70.3 \\
\hline 1831 & 78.8 & 74.0 & 106.5 \\
\hline 1832 & 121.2 & 74.0 & 163.7 \\
\hline 1833 & 75.0 & 81.8 & 91.7 \\
\hline 1834 & 99.0 & 100.6 & 98.4 \\
\hline 1835 & 107.7 & 100.6 & 107.0 \\
\hline 1836 & 107.7 & 103.9 & 103.7 \\
\hline 1837 & 128.8 & 101.3 & 127.2 \\
\hline 1838 & 96.2 & 100.0 & 96.2 \\
\hline 1839 & 98.1 & 125.3 & 78.3 \\
\hline 1840 & 113.5 & 110.4 & 102.8 \\
\hline 1841 & 119.2 & 100.6 & 118.5 \\
\hline 1842 & 107.7 & 95.5 & 112.8 \\
\hline 1843 & 84.6 & 74.0 & 114.3 \\
\hline 1844 & 69.2 & 64.9 & 106.6 \\
\hline 1845 & 90.4 & 70.8 & 127.7 \\
\hline 1846 & 96.2 & 69.5 & 138.4 \\
\hline 1847 & 86.5 & 61.0 & 141.8 \\
\hline 1848 & 88.5 & 59.1 & 149.7 \\
\hline 1849 & 71.2 & 55.8 & 127.4 \\
\hline 1850 & 77.5 & 64.9 & 119.4 \\
\hline 1851 & 87.6 & 59.7 & 146.7 \\
\hline 1852 & 93.2 & 76.6 & 121.6 \\
\hline 1853 & 112.2 & 104.5 & 107.3 \\
\hline 1854 & 108.7 & 124.0 & 87.6 \\
\hline 1855 & 78.8 & 131.2 & 60.1 \\
\hline 1856 & 88.5 & 111.7 & 79.2 \\
\hline 1857 & 92.3 & 101.9 & 90.5 \\
\hline 1858 & 71.2 & 114.3 & 62.3 \\
\hline 1859 & 94.2 & 109.7 & 85.9 \\
\hline 1860 & 107.7 & 98.7 & 109.1 \\
\hline
\end{tabular}

This article is protected by copyright. All rights reserved. 


\begin{tabular}{lccc}
\hline 1861 & 100.0 & 100.0 & 100.0 \\
1862 & 84.6 & 100.6 & 84.1 \\
1863 & 88.5 & 98.7 & 89.6 \\
1864 & 88.5 & 92.9 & 95.3 \\
1865 & 80.8 & 89.6 & 90.1 \\
1866 & 96.2 & 91.6 & 105.0 \\
1867 & 100.0 & 87.7 & 114.1 \\
1868 & 73.1 & 83.8 & 87.2 \\
1869 & 65.4 & 83.8 & 78.1 \\
1870 & 71.2 & 83.1 & 85.6 \\
1871 & 57.7 & 83.1 & 69.4 \\
\hline
\end{tabular}

Sources: Prices for greasy merino wool from Vamplew, Australians, p. 116. The GDP deflator is from M. Butlin et at., 'Statistical appendix', Table A7.

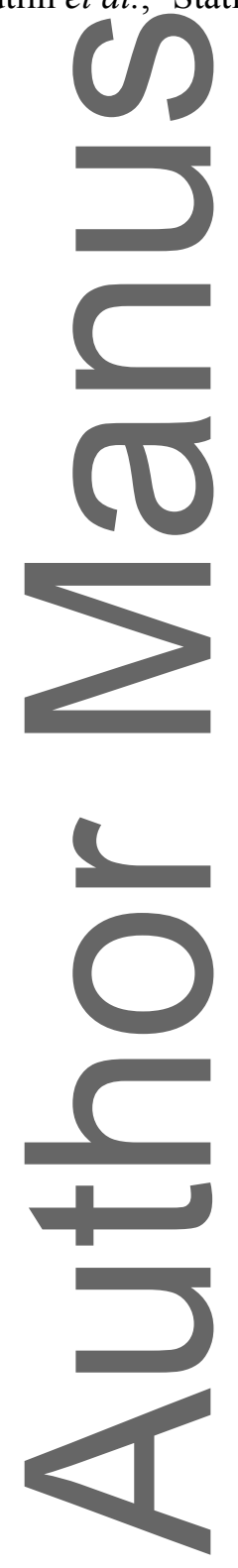

This article is protected by copyright. All rights reserved. 
Table 5: Average Annual Earnings of Convict ( $w c$ ) and Free Labour ( $w f)$, in £, and the Implied Landlord Subsidy 1828-1850.

\begin{tabular}{|c|c|c|c|c|c|}
\hline Year & $\begin{array}{l}\text { Free unskilled } \\
\text { average annual } \\
\text { earnings }\end{array}$ & $\begin{array}{l}\text { Convict average } \\
\text { annual earnings }\end{array}$ & $\begin{array}{l}\text { Convict } \\
\text { labour force } \\
(000)\end{array}$ & $\begin{array}{c}\text { Convict farm } \\
\text { labour share } \\
(\%)\end{array}$ & $\begin{array}{l}\text { Landowner } \\
\text { Subsidy (£) }\end{array}$ \\
\hline & & $(w c)$ & $(L c)$ & $(L c a / L c)$ & $(w f-w c) L c a / r A$ \\
\hline 1828 & 29.88 & 17.63 & 10.88 & 0.48 & 21.61 \\
\hline 1829 & 29.96 & 17.68 & 12.48 & 0.47 & 15.83 \\
\hline 1830 & 30.03 & 17.72 & 14.35 & 0.46 & 14.24 \\
\hline 1831 & & 17.75 & 16.52 & 0.46 & 16.37 \\
\hline 1832 & & 17.78 & 19.04 & 0.45 & 17.43 \\
\hline 1833 & & 17.80 & 21.96 & 0.45 & 24.14 \\
\hline 1834 & 42 & 17.95 & 24.71 & 0.44 & 19.26 \\
\hline 1835 & & 18.07 & 27.90 & 0.44 & 16.66 \\
\hline 1836 & & 18.18 & 31.58 & 0.44 & 17.33 \\
\hline 1837 & 31.60 & 18.65 & 33.09 & 0.43 & 17.31 \\
\hline 1838 & 32.26 & 19.03 & 34.93 & 0.43 & 32.18 \\
\hline 1839 & & 19.36 & 37.12 & 0.42 & 33.22 \\
\hline 1840 & 5.70 & 21.06 & 39.67 & 0.42 & 15.23 \\
\hline 1841 & 38.84 & 22.91 & 42.59 & 0.41 & 44.50 \\
\hline 1842 & 42.25 & 24.93 & 36.57 & 0.41 & 39.25 \\
\hline 1843 & & 27.12 & 30.88 & 0.40 & 41.28 \\
\hline 1844 & & 29.50 & 25.49 & 0.40 & 37.39 \\
\hline 1845 & 52.42 & 30.93 & 20.36 & 0.39 & 40.38 \\
\hline 1846 & 54.96 & 32.43 & 15.45 & 0.39 & 19.56 \\
\hline 1847 & & 34.00 & 10.75 & 0.39 & 15.03 \\
\hline 1848 & & 35.64 & 6.22 & 0.38 & 10.77 \\
\hline 1849 & 63.34 & 37.37 & 1.85 & 0.38 & 2.89 \\
\hline 1850 & 66.40 & 39.18 & 0.55 & 0.37 & 0.76 \\
\hline
\end{tabular}

Sources: $A$ (acres, 000) are taken from Table 1, and rents per acre $(r)$ are taken from Table 2. Free unskilled labour average annual earnings ( $w f)$ are from Coughlan, Labour and industry, vol. 1 for the 1820s, 1830s, and 1840s, and from House of Commons Sessional Papers for the 1850s, augmented by Coughlan, Labour and industry, vol. 2, for urban common labour where necessary. Convict unskilled labour average annual earnings $(w c)=59 \%$ of that of free labour, a figure estimated in Panza and Williamson, 'Australian exceptionalism'. Agricultural convict labour share $(L c a / L c)$ is assumed to be the same as for the total labour force, taken from Table 1.

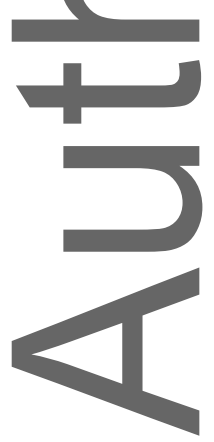

This article is protected by copyright. All rights reserved. 
Table 6. Skill premiums 1828-1867

\begin{tabular}{lll}
\hline Annual earnings and daily wage ratios & 1828 & 1867 \\
\hline Professionals/urban common labour & 25.64 & 6.47 \\
Clerks/urban common labour & 5.86 & 3.42 \\
Carpenters/urban common labour & 2.75 & 1.57 \\
Carpenters/urban common labour & & \\
(including women) & 2.82 & 1.66 \\
Urban common labor/farm labour & 0.71 & 0.86 \\
\hline
\end{tabular}

Sources and notes: The carpenter/urban common labour and the urban common labour/farm labour ratios are based on daily wages from Coghlan, Labour and industry, vols. $1 \& 2$, where 1828 is an average of the 1820s and 1867 an average of the 1860s. The urban unskilled earnings including female domestics are the weighted average of male and female daily wages, where the weights are assigned based on male and female labour force participation, using census data. The other ratios are based on annual earnings from NSW Colonial Blue Books for 1828 and 1867. The category professionals is an average of surveyors and surgeons' earnings.

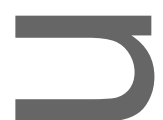

Table 7. Measuring the gap between the middle and the bottom 1830s-1870s

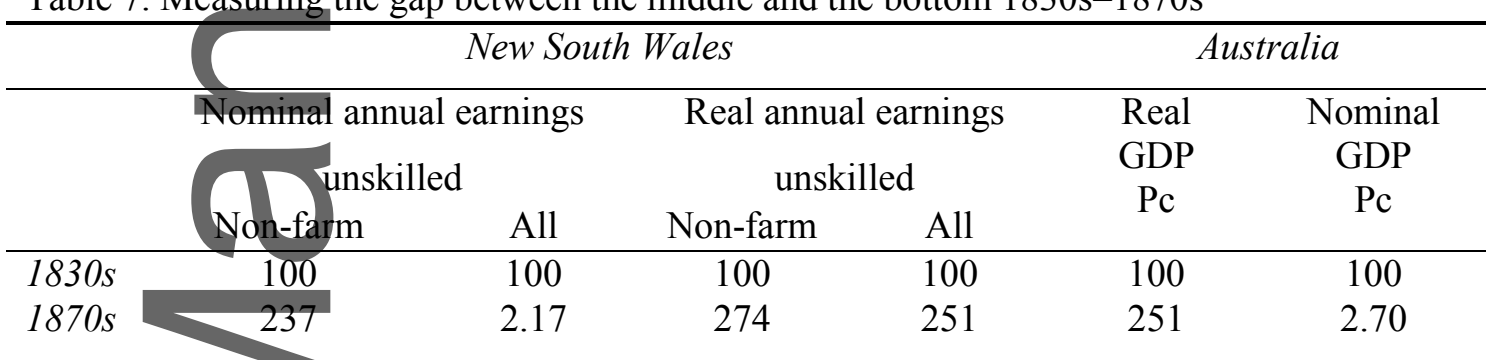

Sources: Real GDP from Butlin et al., 'Statistical appendix', Table A1, pp. 555-8. Labour force 1841-1881 from Butlin et al., 'Statistical appendix', Table A2; 1828-1841; for NSW: Withers and Perry, 'Historical statistics'; linked wages and CPI from Coghlan, Labour and industry, vols. 1 and 2.

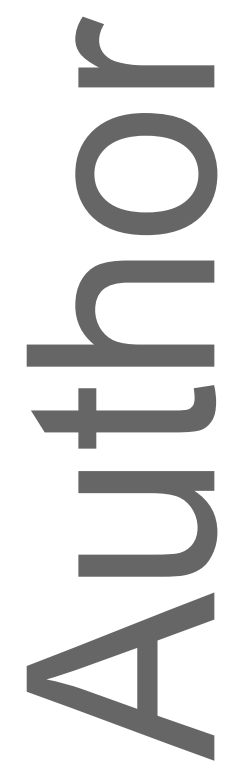

This article is protected by copyright. All rights reserved. 
Table 8: Australian Functional Shares (\%) 1828-1879

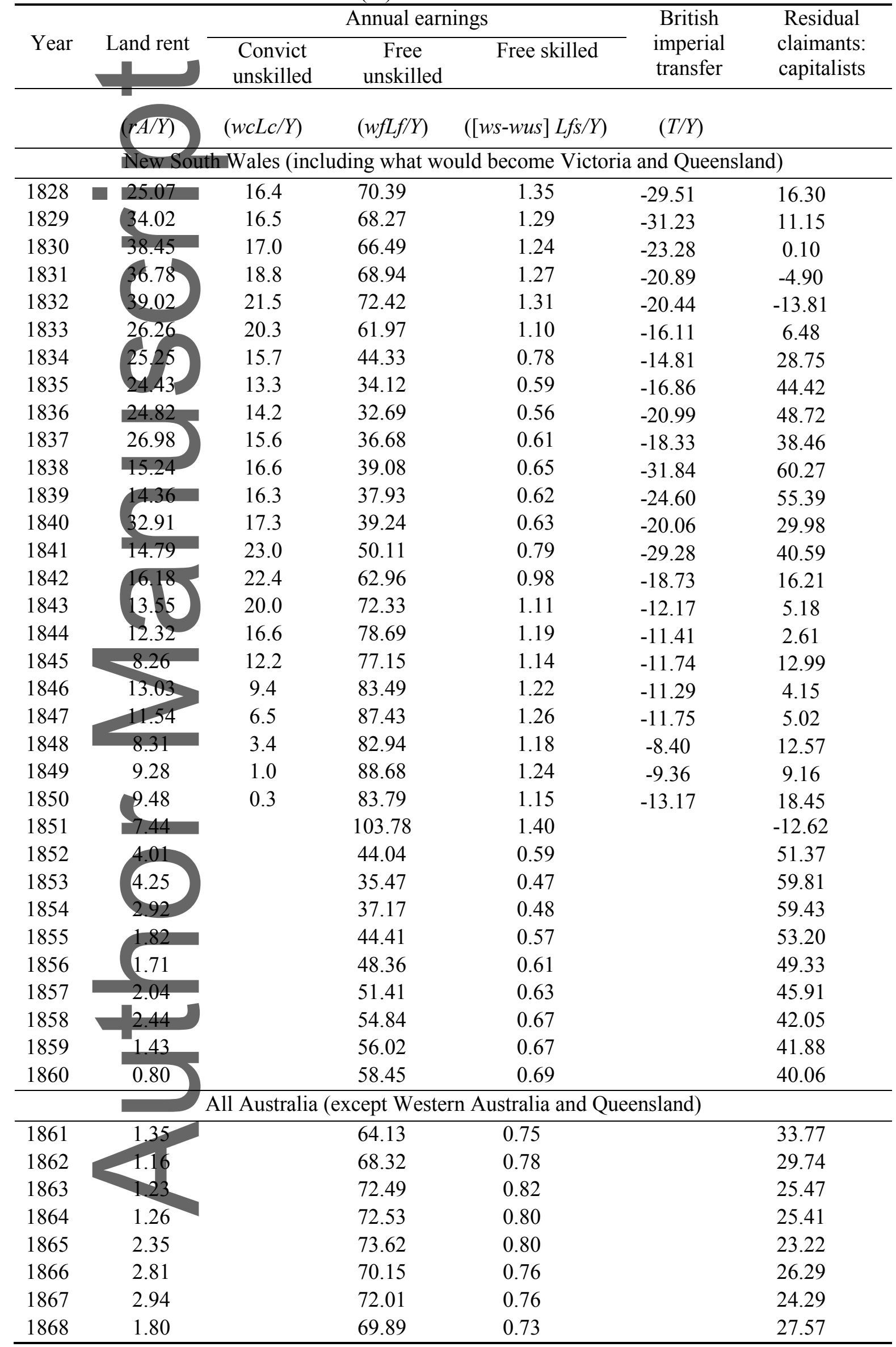

This article is protected by copyright. All rights reserved. 


\begin{tabular}{lllll}
\hline 1869 & 1.42 & 68.36 & 0.70 & 29.51 \\
1870 & 1.72 & 67.78 & 0.69 & 29.82 \\
1871 & 2.21 & 72.80 & 0.73 & 24.27 \\
\hline
\end{tabular}

Sources.Land rents, see Tables 1 and 2; Annual earnings, see Table 5; imperial transfers: from Butlin, Colonial economy, table 10.2.
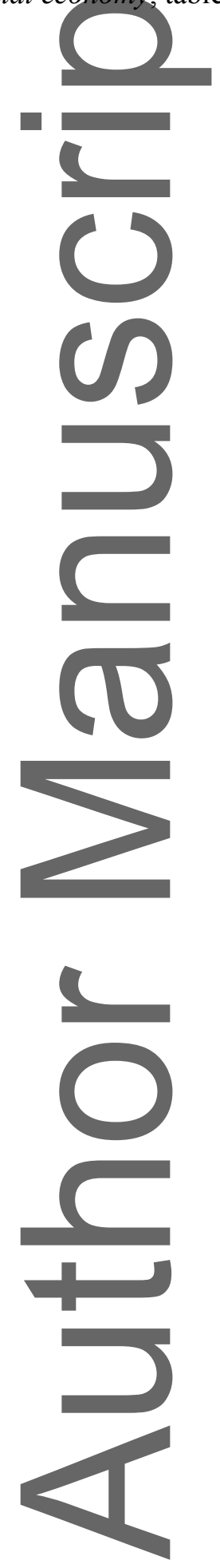

This article is protected by copyright. All rights reserved. 


\section{University Library}

\section{- M M N E R VA A gateway to Melbourne's research publications}

Minerva Access is the Institutional Repository of The University of Melbourne

Author/s:

Panza, L;Williamson, JG

Title:

Australian squatters, convicts, and capitalists: dividing up a fast-growing frontier pie, 1821-71

Date:

2019-05

Citation:

Panza, L. \& Williamson, J. G. (2019). Australian squatters, convicts, and capitalists: dividing up a fast-growing frontier pie, 1821-71. Economic History Review, 72 (2), pp.568-594.

https://doi.org/10.1111/ehr.12739.

Persistent Link:

http://hdl.handle.net/11343/284809 